\title{
ECOSSOCIALISMO, SUAS CATEGORIAS E FUNDAMENTOS TEÓRICOS
}

\author{
EL ECOSOCIALISMO, SUS CATEGORÍAS Y FUNDAMENTOS TEÓRICOS
}

\section{ECOSOCIALISM, ITS CATEGORIES AND THEORETICAL BASEMENTS}

\author{
DOI: http://doi.org/10.9771/gmed.v13i2.44946
}

\author{
Magno da Conceição Peneluc ${ }^{1}$ \\ Edilson Fortuna de Moradillo²
}

\begin{abstract}
Resumo: O Ecossocialismo é um movimento social e um campo de discussão filosófica acerca de um projeto de sociedade que se baseia nos princípios do trabalho livre, consciente, associado e universal, e na defesa da unidade dialética de complementaridade da relação ser social/natureza, sem perder de vista o campo das necessidades e possibilidades postas historicamente para a reprodução humana. Defendemos que as categorias desveladas e as teorias construídas por Marx e Engels possibilitaram a explicitação das contradições materialmente determinadas que o ser humano e a natureza concretizam sob o capitalismo, com base na reprodução do capital e no trabalho assalariado. Buscou-se discutir as teorias que compõem a Economia Ecológica marxista e fundamentam do movimento ecossocialista.
\end{abstract}

Palavras-chave: Ecossocialismo. Economia Ecológica. Limites ecossistêmicos. Resiliência. Produção socialista.

Resumen: El Ecosocialismo es un movimiento social y un campo de discusión filosófica sobre un proyecto de sociedad que se fundamenta en los principios del trabajo libre, consciente, asociado y universal, y en la defensa de la unidad dialéctica de complementariedad de la relación entre ser social / naturaleza, sin perder de vista el campo de necesidades y posibilidades históricamente colocado para la reproducción humana. Sostenemos que las categorías desveladas y las teorías construidas por Marx y Engels permitieron hacer explícitas las contradicciones materialmente determinadas que el ser humano y la naturaleza concretizan bajo el capitalismo, a partir de la reproducción del capital y el trabajo asalariado. Buscamos discutir las teorías que componen la Economía Ecológica Marxista y subyacen al movimiento ecosocialista.

Palabras clave: Ecosocialismo. Economía ecológica. Límites del ecosistema. Resiliencia. Producción socialista.

Abstract: Ecosocialism is a social movement and a field of philosophical discussion about a society project that is based on the principles of free, conscious, associated and universal work, and in the defense of the dialectical unit of complementarity of the relationship between being social / nature, without losing view of the field of needs and possibilities historically posed for human reproduction. We argue that the categories unveiled and the theories constructed by Marx and Engels made it possible to explain the materially determined contradictions that human beings and nature materialize under capitalism, based on the reproduction of capital and wage labor. We sought to discuss the theories that make up the Marxist Ecological Economy and are the foundation of the ecosocialist movement.

Keywords: Ecosocialism. Ecological Economics. Ecosystem limits. Resilience. Socialist production.

\section{Introdução}

Em Os despossuidos (2017a), Karl Marx critica a lógica irracional do direito quando legislado com fins meramente burgueses, com o intuito de favorecer especificamente a classe de proprietários de terra. 
Debate

Terras essas, importante frisar, "adquiridas" por apropriação primitiva, em outras palavras, por meio do furto de um bem comunal, passando assim à apropriação privada. Argumenta que: "o valor é a existência burguesa da propriedade"; ora, da propriedade privada depende a sobrevivência do burguês, então, tornase inaceitável que uma maioria de despossuídos possa coletar madeira caída, "madeira seca ao chão". E o legislador burguês ainda especifica que coletar madeira seca ao chão equivale a cortar madeira das árvores ainda em pé, "subtração de madeira verde". Desta forma, "não há maneira mais elegante e ao mesmo tempo mais simples de derrubar o direito das pessoas em favor do direito das árvores novas (MARX, 2017, p. 56)".

Claro, a Dieta Renana ${ }^{3}$ estava a proteger o direito dos proprietários, não o direito das árvores nem dos despossuídos, Marx estava bem ciente disso. Para além da discussão jurídica, o que Marx enfatizou no referido texto, foi o fato primaz da propriedade privada tomar o lugar da ligação orgânica essencial do ser humano com a natureza, e dela tradicionalmente fazer uso para satisfazer suas necessidades básicas de sobrevivência. A apropriação privada das terras permite ao mesmo tempo que se classifique formalmente os despossuídos enquanto ladrões e protege o proprietário para fazer o que bem entender com o que é "seu por direito". Qualquer ato que não seja em favor do interesse do proprietário privado é um atentado contra ele e contra a propriedade. Portanto, "quem furta madeira cortada furta propriedade. No caso da madeira caída no chão, em contraposição, nada é tirado da propriedade (MARX, 2017a, p. 56)".

Mas essa mesma forma de apropriação privada da natureza implica na intensidade da sua destruição e repercute obviamente na preocupação de Marx com as vidas humanas, com a injustiça que emerge da prevalência da propriedade privada e de seus efeitos jurídicos, já que o proprietário visa utilizar a madeira e a terra para a produção de excedentes e não para a satisfação de necessidades humanas elementares de sobrevivência, a qual fica subsumida pela primeira. Em função desse fato, posiciona-se enfaticamente:

Reivindicamos para a pobreza o direito consuetudinário, mais precisamente um direito consuetudinário que não seja local, mas que constitua o direito consuetudinário da pobreza em todos os países. Vamos ainda além e afirmamos que, por sua natureza, o direito consuetudinário só pode ser o direito dessa massa mais baixa, sem posses e elementar (MARX, 2017a, p. 59).

Nos Manuscritos Econômico-filosóficos de 1844, foram definidos fundamentos essenciais de seu pensamento, em especial a ontologia de ser social, que tem o trabalho como categoria fundante e eixo condutor para compreender os diversos processos que vão se estruturando ao longo da história para dar conta da reprodução humana. Processos esses que vão além do trabalho propriamente dito de mediação do ser social com a natureza e que vão ganhando autonomia própria, a exemplo da educação, política, economia, direito, ciência, filosofia, etc (autonomia relativa, é bom que se diga), tendo a economia política como momento predominante dessa reprodução, e que considerando as condições históricas, pode conduzir à alienação humana no seio do próprio processo produtivo, como decorrência das formas de 
propriedade prevalecente na sociedade e na forma como as relações de trabalho se concretizam ao longo da história (MARX, 2006).

Já na primeira das Teses sobre Feuerbach, Marx (1999) criticou todo o materialismo a ele anterior, por conceber a realidade como proveniente simplesmente das sensações e não como atividade sensorial humana, daí também a prevalência do idealismo estranho à atividade real e objetiva dos seres humanos. Para Marx “a vida social é essencialmente prática (MARX,1999, p. 7)”. O que significa dizer que a compreensão da realidade parte da atividade humana concreta e historicamente fundada para dar conta da sua existência, constituída a partir de uma objetividade concreta e materialmente determinada. Portanto, parte das relações materiais de produção da nossa existência e a ela retorna, após intenso processo de reflexão ativa, expresso na construção da teoria, fruto de uma síntese dialética. Essa concepção materialista fundamenta-se na premissa de que a realidade humana, tanto no que se refere às condições prévias à sua ação, como no tocante às suas próprias condições materiais, é produzida pela sua própria ação, dentro de um campo de possibilidades dado na materialidade objetiva e histórica da realidade social, objetivando dar conta da existência (as necessidades postas historicamente). O corolário é que toda a história humana é, naturalmente, a presença de indivíduos humanos vivos e o primeiro fato a constatar é, portanto, a organização física destes indivíduos e a sua relação com a natureza, sempre procurando dar conta da sua existência, sempre procurando dar conta da vida (MARX; ENGELS, 1982).

É bom frisar que, por um processo evolutivo, e com o salto ontológico da matéria inanimada para a matéria orgânica/vida e dessa, passando por diversos processos de ampliação da complexidade e reflexos dos seres vivos, chegamos ao ser social, o qual ao se configurar na sua complexidade inerente, onde aparece a consciência como desenvolvimento tardio da matéria - a consciência é sempre a consciência de um ser consciente -, passa a existir conscientemente no seio do grupo social de primatas que the deu origem. Assim, o indivíduo já aparece por dentro do grupo social que ele se originou, isto é, não existe o primeiro primata, e sim grupos de primatas que evoluíram, ou, dito de uma outra forma, o indivíduo só existe na relação com o "nós". Não existe indivíduo abstratamente colocado, e sim o indivíduo numa relação de horizontalidade com o "nós" (os outros seres humanos) e a natureza-natural4. A natureza-natural, assim como os outros seres humanos, passam a ser meu complemento e não, simplesmente, a forma da minha realização, conforme pensamento dominante atualmente, modulado pela forma como organizarmos a nossa existência por dentro de relações reprodutoras do capital ${ }^{5}$. Nessas relações hodiernas o indivíduo está acima do "nós" e da natureza-natural, desta forma, ele é inflacionado, elevado a décima potência, campo fértil para uma ética transcendente em contraposição a uma ética imanente $^{6}$ a qual defendemos.

A Natureza é concebida como uma categoria fundamental da ontologia do ser humano, da qual, ao obstar-se, passa a inexistir, ou, na melhor das hipóteses, passa a ser o meio da minha realização, em vez de ser o meu/nosso complemento. O ser humano nada pode criar sem a natureza, o mundo exterior sensível. A natureza é a matéria do seu trabalho, a partir da qual e por meio da qual produz sua existência (MARX, 2008a). Logo, não há qualquer cisão entre ser humano e natureza, já que 
as determinações que valem para a produção em geral podem ser precisamente separadas, a fim de que não se perca de vista a diferença essencial por causa da unidade, a qual decorre já do fato de que o sujeito - a humanidade - e o objeto - a natureza são os mesmos (MARX, 2007, p. 237).

Marx se inspirou grandemente na dialética materialista, mas não determinista, de Epicuro. Reconhecido filósofo da sensibilidade, Epicuro salientava a transitoriedade da existência e da vida. O método desenvolvido por Marx o ajudou a superar a filosofia idealista de Hegel, adotando uma filosofia humanista-materialista. Em outras palavras: "para Marx, nós transformamos a nossa relação com o mundo e transcendemos nossa alienação dele - criando as nossas próprias relações distintamente bumano-naturalis -, pela ação, isto é, através da nossa práxis material (FOSTER, 2005, p. 18)."

A noção de que a formação ontológica do ser social é histórico-natural, ou seja, histórica no que concerne ao processo de desenvolvimento das organizações sociais e formações econômicas humanas ao longo do tempo; mas natural, poia a natureza é condição inalienável da constituição das sociedades humanas, já que é meio de produção e condição de existência biológica. Assumimos essa noção e buscamos realizar uma investigação teórica sobre os fundamentos filosóficos marxianos que viabilizaram a construção histórica do Ecossocialismo e da construção teórica da ciência da Economia Ecológica marxista.

Defendemos a tese de que as categorias desveladas e as teorias construídas por Marx e Engels possibilitaram a explicitação das relações dialéticas históricas, materialmente determinadas, que o ser humano e a natureza concretizam sob o capitalismo, com base na reprodução do capital e no trabalho assalariado; e que isso levou à construção de teorias ecomarxistas que explicam as implicações ecológicas do desenvolvimento do capitalismo imperialista, de forma dialética. Desta forma, o acúmulo por expropriação, a expansão espaço-temporal do capital e o aumento na taxa de lucro derivado dos ciclos de superprodução e de consumo, a pauperização crescente e a intensificação da produção de excedentes, a circulação ampliada de mercadorias, relacionam-se com a produção de resíduos (enfatizando a relação produção-consumo e o ciclo de vida dos materiais), com a escassez e a poluição dos meios naturais (água, terra, biodiversidade, ar) e com as alterações climáticas. Portanto, nosso objetivo é discutir teorias ecomarxistas e apontar para possíveis repercussões teóricas acerca da conformação da Economia Ecológica marxista e para a fundamentação do movimento de luta Ecossocialista.

\section{Trabalho e ontologia do ser social}

O trabalho, atividade mediadora primaz que o ser humano emprega na natureza, não quer dizer outra coisa senão que o trabalho é "a universalidade abstrata da atividade criadora de riqueza, tem-se agora igualmente a universalidade do objeto determinado como riqueza, o produto em geral, ou ainda o trabalho em geral, mas como trabalho passado, objetivado (MARX, 2011, p. 86)". A relação material do ser humano com a natureza é que viabiliza a construção histórica do indivíduo e das sociedades, a humanidade genérica, a espécie, já que o próprio homem também é necessariamente natureza. Ou seja: 
"cada individualidade é composta por diversos elementos: o indivíduo, os outros homens e a natureza (...). O homem não entra em relações com a natureza simplesmente pelo fato de ser ele mesmo natureza, mas ativamente, por meio do trabalho, técnica (GRAMSCI, 1996, p. 39)".

György Lukács construiu uma argumentação filosófica sobre a formação histórica do ser social e um tratado sobre a ontologia na filosofia marxiana. A formação histórica do ser social foi encarada por Marx, conforme descreve Lukács (2010), como uma conexão entre três tipos diferentes e complementares de ser: o ser da natureza inorgânica, o ser da natureza orgânica e o ser da sociedade. O ser humano pertence obviamente à esfera do ser social, entretanto, como ser social só pode existir devido ao seu ser biológico, sua gênese, transcurso e fim da sua existência, que contém a sua matéria inorgânica; assim, por saltos ontológicos ocorridos ao longo do processo histórico-evolutivo da matéria, o ser social representa a máxima complexidade existente na matéria atualmente, pois incorpora a matéria inorgânica (processos físico-químicos), a matéria orgânica (processos físico-químicos e biológicos) e a matéria social (processos físico-químicos, biológicos e conscientes); assim como mantém contínua e ininterruptamente relação com as três esferas, sendo impossível seu desenvolvimento na esfera social se fosse de outra forma. Esta concepção ontológica é, de acordo com a filosofia lukacsiana, indispensável para todo pensamento humano, sendo que este pensamento deriva desta noção ontológica, mas que também a modifica e a consolida. Conforme explica Engels (2015, p. 45), de forma dialética: “do mesmo modo, todo ser orgânico, a cada instante, é o mesmo e não é o mesmo; a cada instante ele processa substâncias trazidas a ele de fora e excreta outras; a cada instante morrem células do seu corpo e novas se formam (...)”.

O ser social é constituído, portanto, por três seres indistintamente entrelaçados, mas com uma dinâmica, um movimento que distingue o ser social: a prévia-ideação, que conduz ao pôr teleológico definidor da intencionalidade imediata viabilizada pela práxis:

os três tipos de ser existem simultaneamente, entrelaçados entre si, e exercem também efeitos muitas vezes simultâneos sobre o ser do homem, sobre sua práxis. É preciso ter sempre em mente que uma fundamentação ontológica correta de nossa imagem de mundo pressupõe as duas coisas, tanto o conhecimento da propriedade específica de cada modo de ser como o de suas interações, inter-relações etc. com os outros. Nas duas direções, o desconhecimento da verdadeira relação (unidade na diversidade, por meio dela a separação e a oposição nas interações homogêneas etc.) pode conduzir às maiores distorções do conhecimento daquilo que é o ser. O ser humano pertence ao mesmo tempo (e de maneira difícil de separar no pensamento) à natureza e à sociedade. Esse ser simultâneo foi mais claramente reconhecido por Marx como processo, na medida em que diz, repetidas vezes, que o processo do devir humano traz consigo um recuo das barreiras naturais (LUKÁCS, 2010, p. 37).

É necessário que se entenda esse contínuo recuo das barreiras naturais. Ele não significa necessariamente alienação, embora no capitalismo este fenômeno de fato aconteça; mas Lukács se refere ao fator peculiar do ser social: a práxis, especificamente a práxis teleologicamente guiada. Seu caráter particularmente humano, mas que não o descaracteriza enquanto natureza, ao contrário, a unidade dos contrários se fortalece por este mesmo contínuo movimento de afastamento das barreiras naturais. E dialeticamente tem todo sentido assumir o afastamento do gênero humano da natureza, pois ao mesmo 
tempo em que se afasta da natureza, mais se entrelaça em sua natureza humana (humanizada), numa unidade dialética:

Esse processo, em grande parte inconsciente, iniciou-se já nos mais rudimentares estágios do trabalho, e paulatinamente tornou-se um meio universal de domínio do homem sobre seu ambiente, instrumento adequado daquilo que distingue o trabalho, como adaptação ativa do homem ao seu ambiente, de qualquer adaptação pré-humana. Naturalmente, o pôr teleológico consciente constitui aqui a verdadeira linha de separação primária. Mas, como o desenvolvimento ilimitado dessa adaptação ativa se distingue, ontologicamente, das formas de adaptação passivas, antigas, fundadas apenas biologicamente e por isso, em sua essência, relativamente estáticas, exatamente a desantropomorfização é um elemento de decisiva importância para a humanização do ser humano, para o recuo das barreiras naturais em seu processo social reprodutor como indivíduo e como gênero. Sem esse processo, para voltarmos ao nosso problema, muitas manifestações diretas da vida cotidiana humana formariam barreiras insuperáveis para tal práxis e, com isso, para o autêntico conhecimento do ser por parte dos homens (LUKÁCS, 2010, p. 57).

Deste processo de humanização é que se funda o gênero (no sentido mesmo de espécie) humano não mudo, superando por incorporação o mutismo da natureza - este novo ser, não mais mudo, torna-se assim social pelo processo mediador primordial, o trabalho -, e posteriormente, consubstanciado pelos complexos da linguagem e da sociabilidade. É por isso que Lukács fala de adaptação ativa como a adaptação característica do gênero humano, já que teleologicamente guiada7 .

O ser da natureza inorgânica, o ser da natureza orgânica e o ser da sociedade - estabelecidos enquanto componentes ontológicos do ser social, com efeito, apenas compõem o início da composição histórica deste ser. O fator fundante do processo ontológico da formação do ser social é o trabalho. Foi justamente em função da centralidade ontológica do trabalho que Marx compreendeu que o trabalho é a única atividade humana que incute valor à natureza, transformando-a em valores úteis ao ser humano. $\mathrm{E}$ esta atividade é o que explica a opção lógica de Marx em centrar seus esforços na Economia Política, a ciência que estuda os modos de produção de valor, sua distribuição, circulação e realização. Considerando a base da atividade econômica, o trabalho é o centro - é ele que torna possível a produção de qualquer bem, criando os valores que constituem a riqueza social. As condições materiais de existência e de reprodução da sociedade obtêm-se na relação com a natureza (NETTO; BRAZ, 2009).

O caráter universal do trabalho é enfatizado por Marx, pois seu produto é o único meio de garantir a sociabilidade humana. Ou seja: "desde que, os homens, não importa o modo, trabalhem uns para os outros, adquire o trabalho uma forma social (MARX, 2008b, p. 93)”. Isto é:

O trabalho, como criador de valores de uso, como trabalho útil, é indispensável à existência do homem - quaisquer que sejam as formas de sociedade - é necessidade natural e eterna de efetivar o intercâmbio material entre o homem e a natureza (MARX, 2008b, p. 65).

O ser humano foi tornando-se historicamente humano por meio da práxis concretizada pelo trabalho, mediação com a natureza e viabilizador da própria existência do ser social. O ato laborativo, na verdade, é uma fusão entre ação teleologicamente posta e causalidade (LUKÁCS, 2010). A esfera biológica 
não desaparece e logicamente a contínua transformação da natureza não implica necessariamente sua destruição. Assim:

Os homens apenas podem viver se efetivarem uma contínua transformação da natureza. Diferentemente do que ocorre na esfera biológica, essa transformação da natureza é teologicamente posta; seu resultado final previamente construído na subjetividade sob a forma de uma finalidade que orientará todas as ações que virão a seguir. (...) Os atos de trabalho, contudo, apenas podem vir a ser e se desenvolver tendo por mediação dois complexos sociais fundamentais. Por um lado, apenas podem ocorrer no interior de relações sociais; por outro lado, nem as relações sociais nem sequer a prévia ideação portadora da finalidade poderiam vir a ser sem a linguagem. Portanto, já no seu momento primordial, o ser social comparece como um complexo constituído, pelo menos, por três categorias primordiais: a sociedade, a linguagem e o trabalho (LESSA, 1996, p. 9-10).

A concepção da dialética entre a natureza e os seres humanos, tornou-se historicamente possível a compreensão do que os seres humanos realmente são, do que os articula e os distingue da natureza. Tendia-se compreender-nos como decorrência direta e imediata da natureza. Mas Marx consegue compreender de forma radical o ser humano: pelo trabalho, ao transformar a natureza, a humanidade cria novas possibilidades e necessidades objetivas (LESSA; TONET, 2011). Já que “(...) é unicamente por meio do trabalho que o homem aumenta o valor dos produtos naturais e o trabalho constitui propriedade ativa do homem (MARX, 2006, p. 70)”. Enquanto propriedade ativa, o trabalho, segundo Marx é o meio pelo qual a humanidade se objetiva na história, produzindo sua existência. Em decorrência das formas de produção da sua própria existência, o ser humano, considerando suas organizações sociais, constitui objetivamente seu corpo e suas imagens ideológicas da natureza. Ou seja: "o trabalho, atividade vital, a vida produtiva é o único meio que satisfaz a sua existência física. A vida como meio de vida (MARX, 2006, p. 116)". "O trabalho implica, pois, um movimento indissociável em dois planos: num plano subjetivo (pois a prefiguração se processa no âmbito do sujeito) e num plano objetivo (que resulta na transformação material da natureza); assim, a realização do trabalho constitui uma objetivação do sujeito que o efetua (NETTTO; BRAZ, 2009, p. 32)”. Desta forma o trabalho é

(...) um processo de que participam o homem e a natureza, processo em que o ser humano, com sua própria ação, impulsiona, regula e controla o intercâmbio material com a natureza. Defronta-se com a natureza como uma de suas forças. Põe em movimento as forças naturais do seu corpo - braços, pernas, cabeça e mãos - a fim de apropriar-se dos recursos da natureza, imprimindo-lhes forma útil à vida humana. Atuando assim sobre a natureza externa e modificando-a, ao mesmo tempo modifica a sua própria natureza. Desenvolve as potencialidades nela adormecidas e submete ao seu domínio o jogo das forças naturais. Não se trata aqui das formas instintivas, animais, de trabalho. Quando o trabalhador chega ao mercado para vender a sua força de trabalho, é imensa a distância histórica que medeia entre sua condição e a do homem primitivo com a sua forma mais instintiva de trabalho. Pressupomos o trabalho sob sua forma como forma exclusivamente humana (MARX, 2008a, p. 211).

Esse ser histórico-natural é fundamental ao Ecossocialismo, pois pretende compreender as múltiplas determinações deste ser social, na totalidade das relações ser humano-natureza - incorporando e superando as relações de causa-efeito -, como as condições históricas de luta de classes determinam-se reciprocamente com a apropriação privada dos meios de produção naturais, a relação entre produção e 
consumo, produção de resíduos, poluição, destruição de hábitats, depleção da biodiversidade; em suma, com o comprometimento da resiliência dos ecossistemas -, compreendidos como processo histórico que de forma dialética interferem na relação entre o ser humano e a natureza, objeto da ciência da Economia Ecológica de base marxiana.

É importante estar ciente da definição ontológica do ser social para que se evite noções maniqueístas e ingênuas, seja demonizando o ser humano (sem fazer a devida distinção das classes sociais envolvidas nos processos de degradação da natureza), seja propondo apenas soluções tecnicistas (baseadas na ecoeficiência) ou concebendo a natureza de forma romântica e idílica. Isto pode restringir a discussão a apenas um dos complexos componentes do ser social, o que empobreceria decisivamente quaisquer pesquisas que tenham como objeto central compreender dialeticamente a relação ser humano-natureza.

\section{Trabalho, valor, mercadoria e meios de produção: como estas categorias definem a relação ser}

\section{humano-natureza?}

Para compreender a relação sociometabólica que o ser social concretiza com a natureza ao longo da história da sociedade capitalista, certas categorias e teorias marxianas são fundamentais. Especificamente no que concerne ao modo produção de mercadorias, ao processo social de troca de valores (circulação), o consumo, a emergência e relevância do equivalente universal de valores (o dinheiro), as relações de trabalho, a divisão social do trabalho e suas consequências à composição infraestrutural e superestrutural da sociedade ${ }^{8}$. A seguir serão discutidas as implicações dessas categorias na compreensão da relação ser humano-natureza no âmbito do capitalismo contemporâneo.

A mercadoria, este ente social, a base material que é materializada pela ação intencional humana é repleta de objetivações que corporificam as relações sociais ocorrentes durante o processo produtivo. Ou seja:

A mercadoria é, antes de mais nada, um objeto externo, uma coisa que, por sua propriedade, satisfaz as necessidades humanas, seja qual for a sua natureza, a origem delas, provenham do estômago ou da fantasia. Não importa a maneira como a coisa satisfaz a necessidade humana, se diretamente, como meio de subsistência, objeto de consumo; ou indiretamente, como meio de produção (MARX, 2008b, p. 57).

Esta propriedade geral - a de satisfazer as necessidades humanas -, foi explicitada por Marx a partir também da sua relação com outras características particulares que se materializariam a partir do condicionamento histórico da mercadoria nas sociedades capitalistas. Mas para ser chamada de mercadoria, esta coisa que corporifica (materializa, objetiva) o trabalho humano teve de ser materializada em função de um determinado fim: a satisfação de uma dada necessidade humana. Para compreender esse processo de constituição da mercadoria como coisa que possui um fim histórico previamente determinado, Marx teve que distinguir qual o meio propriamente humano capaz de incutir valor à natureza, podendo assim modificá-la em um bem útil à humanidade. Esse meio é o trabalho.

Mas a consequência primordial da concretização do ato laborativo ao transformar a natureza foi concebida historicamente como uma atribuição dotada de um caráter objetivamente relevante para a 
realização da relação social, uma mediação de segunda ordem. Em outras palavras, para que o ato da troca se realize, o objeto já alterado pelo trabalho humano deve possuir um determinado quantum de valor. Segundo Marx (2008b, p. 58): “a utilidade de uma coisa faz dela valor de uso. (...) O valor de uso só se realiza com a utilização, com o consumo. Os valores de uso constituem o material da riqueza, qualquer que seja a forma social dela".

Mas não se deve confundir a produção de valores de uso como ocorria nas comunidades primitivas com as mercadorias produzidas no seio do capitalismo.

De uma forma geral, desde as comunidades primitivas, passando pelas escravagistas e pelo feudalismo, os modos de produção foram se alterando progressivamente pelos processos de sedentarismo, da domesticação de animais e da agricultura, propiciando o desenvolvimento de forças produtivas e afastamento das barreiras naturais, com consequente melhoramentos das condições de reprodução da vida e ampliação populacional das comunidades. Um salto qualitativo se deu com o início da produção de excedentes no período neolítico (a revolução neolítica), propiciando o surgimento da propriedade privada, das classes sociais e exploração do trabalho alheio, com seus diversos complexos sociais necessários para estabilizar tais relações, a exemplo do direito, estado, exército, casamento monogâmico, dentre outros (LESSA; TONET, 2011). Do período neolítico até os dias de hoje as formas de exploração do trabalho alheio se alteraram, associado a um determinado modo de produção prevalente; a grosso modo podemos dizer que transita do trabalho escravo (sociedade escravista, modo de produção escravista) para o trabalho servil (sociedade feudal, modo de produção feudal), até chegar no trabalho assalariado (sociedade reprodutora do capital, modo de produção capitalista dominante).

O valor de uso nas sociedades primitivas era a base das relações de produção da existência das comunidades, as trocas eram incipientes e eventuais, chegando, na sociedade atual, a um nível de complexidade no qual o valor de troca se sobressai e subsumi o valor de uso, tornando a produção de mercadorias algo sistêmico.

$\mathrm{Na}$ transição da sociedade feudal para a sociedade capitalista - isto bem caracterizado na Europa e parte do norte da América - podemos constatar, a primeira fase da sedimentação da sociedade capitalista, o período da acumulação primitiva, no qual domina o capitalismo comercial (do Sec. XV ao último terço do Séc. XVIII), marcado pelos mercadores e pela troca de bens acumulados (mercadoria) associada com a exploração do trabalho, aqui ainda caracterizado pelo artesanato especializado, o que já demonstra um gérmen da nova divisão social do trabalho (NET'TO; BRAZ, 2009).

Os valores são na realidade dotados de duas propriedades: são ao mesmo tempo constituídos por um valor útil para um determinado ser humano (como uma camisa ou dois pães); assim como corporificam uma determinada utilidade para outrem, haja visto que o produtor só se dirigiria ao mercado para trocar sua camisa se tivesse alguém disposto a trocá-las por 30 pães, por exemplo; neste caso referimo-nos ao valor de troca.

No capitalismo já sedimentado (final do Séc. XVIII em diante), com efeito, as mercadorias são itens dotados destes dois tipos de valores, porém, desde o princípio da produção e depois, na esfera da 

acúmulo de excedentes, intensifica-se a exploração do trabalho e a produção de mercadorias passa a ser o fim-em-si do processo produtivo. "O valor de troca revela-se, de início, na relação quantitativa entre valores de uso de diferentes especiais, na proporção em que se trocam, a relação que muda constantemente no tempo e no espaço (MARX, 2008b, p.58)". Conforme Marx (2007) esclarece, enquanto meio de existência, os valores de uso são produtos da força de trabalho humana, trabalho objetivado. Mas os valores de uso, para que se concretizem, necessitam da essência natural, e a humanidade apropria-se da natureza sob a forma de intercâmbio entre ser humano e natureza.

A atualidade do pensamento de Marx no que concerne às questões socioambientais é reveladora quando pensamos na relação entre demanda e escassez dos meios de produção, pois: "as condições naturais de escassez ou abundância parecem determinar o valor de troca das mercadorias, porque determinam a força produtiva, ligada às condições naturais, de um trabalho concreto particular (MARX, 2007, p. 62)". No que tange à manutenção do trabalhador, em termos orgânicos (de subsistência biológica), o capitalista paga na verdade apenas a função de certa quantidade de bens de subsistência. Mas no que se refere à acumulação de capital, a expansão da produção é condicionada pela transformação de mais-valor em capital adicional e, por conseguinte, também pela expansão de capital que forma a base da produção (MARX, 1984). E o que resulta do processo de produção de mais-valor e da circulação de mercadorias é uma relação organicamente invertida, considerando que se produ乏 para a troca e não para a satisfação das necessidades humanas. No capitalismo se dá um processo de coisificação das pessoas e de bumanização das mercadorias, pois o que caracteriza o trabalho sob o capitalismo é que “(...) as relações sociais das pessoas aparecem invertidas, como a relação social das coisas. O valor de troca passa a determinar os valores de uso na sociedade. Porém, sabe-se que a relação entre as mercadorias na realidade é uma relação entre pessoas (MARX, 2007, p. 58)". Dado que “toda produção é apropriação da natureza pelo indivíduo no interior de e mediada por uma determinada forma de sociedade (MARX, 2011, p. 60).”

Cabe atentar para as mediações que a sociedade lança mão para incutir valor aos bens naturais (meios de produção). As relações pessoais, no capital, encontram-se dissolvidas, pois as relações entre produtores, e por definição, o tempo de trabalho gasto para produzir um dado valor não mais são os fatores centrais que definem o valor dos bens produzidos. Os produtos não possuem mais caracteres específicos e voltados ao uso, já que de início são produzidos de forma geral e impessoal para a troca. Todavia, o valor de uso se constitui (ou deveria se constituir) do tempo de trabalho médio socialmente necessário à reprodução da sociedade. De maneira distintiva:

Uma coisa pode ser valor de uso sem ser valor (valor de troca, mercadoria). É o que sucede quando sua utilidade para o ser humano não decorre do trabalho. Exemplos: o ar, a terra virgem, seus pastos naturais, a madeira que cresce espontânea na selva, etc. Uma coisa pode ser útil e produto do trabalho humano sem ser mercadoria. Quem, com seu produto, satisfaz a própria necessidade gera valor de uso, mas não mercadoria. Para criar mercadorias, é mister não só produzir valor de uso, mas produzi-lo para outros, dar origem a valor de uso social. Finalmente, nenhuma coisa pode ser valor se não é objeto útil; se não útil, tampouco o será o trabalho nela contido, o qual não conta como trabalho e, por isso, não cria nenhum valor. Por exemplo, um casaco é um valor 
de uso pois satisfaz uma necessidade particular. Para produzi-lo, precisa-se de certo tipo de atividade produtiva, determinada por seu fim, modo de operar, objeto sobre que opera, seus meios e seu resultado (MARX, 2008b, pp. 62-63).

Desta forma, a mercadoria é tanto valor de uso como valor de troca, já que guarda seu caráter enquanto possibilidade de sua troca no mercado por outras mercadorias, ou pelo equivalente universal, o dinheiro.

No momento interessa explicitar este fenômeno bem característico: como o possuidor de dinheiro ao qual Marx se refere, "colhe" mais dinheiro ao final do processo de metamorfose de dinheiro em capital? De forma bastante clara, podemos assim compreender este processo:

O capital não é uma coisa, mas um processo em que o dinheiro é perpetuamente enviado em busca de mais dinheiro (...). Mas a forma de circulação de capital que passou a dominar a partir do meado do séc. XVIII é aquela do capital industrial ou de produção. Nesse caso, o capitalista começa o dia com uma certa quantidade de dinheiro e, tendo selecionado uma tecnologia e uma forma organizacional, entra no mercado e compra as quantidades de força de trabalho e meios de produção necessários (matériasprimas, instalações físicas, produtos intermediários, máquinas, energia e assim por diante). A força de trabalho é combinada com os meios de produção por um processo de trabalho ativo realizado sob a supervisão do capitalista. O resultado é uma mercadoria que é vendida no mercado por seu proprietário, o capitalista, por um lucro (HARVEY, 2011, p. 41).

Veremos no decorrer dos próximos capítulos, que a contradição entre a taxa crescente de exploração do trabalho em busca de ampliação dos lucros e a incapacidade de realização do valor decorrente da diminuição de consumo de excedentes, guarda relação dialética com os limites dos meios de produção. Sustentamos, portanto, que a intensificação dessa contradição pode resultar numa tensão crescente sobre estes mesmos meios de produção, que além de serem o próprio trabalho humano, são também recursos/processos naturais, limitados e com uma resiliência ecossistêmica cada vez mais testada aos limites

O bem/recurso natural (a terra, o ar, a água, a biodiversidade, por exemplo) pode ser também chamado de meios de produção, dada sua utilidade quando considerada a sua internalização ao processo produtivo, os quais em algum momento serão valorados. Que se frise: valorados a partir da perspectiva da sua apropriação privada. Há que se compreender que "o poder do homem sobre a natureza, do mesmo modo que os bens produzidos por essa potência estão açambarcados, e a apropriação da natureza pelo homem social se transformou em propriedade privada dos meios de produção (LEFEBVRE, 2010, p. 42)".

Começa a ser explicitada uma contradição importante. Segundo Harvey (2011, p. 46), Marx "contrasta o ilimitado potencial de acumulação monetária, por um lado, com os aspectos potencialmente limitadores de atividade material (produção, troca e consumo de mercadorias), por outro. O capital não consegue tolerar limites". Esta noção é central para a compreensão crítica da relação ser humano/natureza. O capital, em sua forma contemporânea, se caracteriza por uma taxa constante de crescimento de 3\% ao ano. Ou seja, a necessidade de reinvestir em expansão é insopitável, sob risco de comprometer a produção ou desacelerar a circulação, o que geraria crises. A circulação do capital implica 
movimento espacial, onde o dinheiro e os recursos de trabalho são mobilizados e os meios de produção (incluindo matérias primas) têm de ser trazidos de mais de um lugar para produzir mercadorias que têm de ser levadas a um mercado num outro lugar. Este quadro contraditório começa a revelar seus limites quando se vislumbra a totalidade do processo:

O exame do fluxo do capital por meio da produção revela seis barreiras potenciais à acumulação, que devem ser negociadas para o capital ser produzido: capital inicial sob a forma de dinheiro insuficiente; escassez de oferta de trabalho ou dificuldades políticas com esta; meios de produção inadequados, incluindo os limites naturais; tecnologias e formas organizacionais inadequadas; resistências ou insuficiências no processo de trabalho; falta de demanda fundamentada em dinheiro para pagar no mercado (...). Quando os capitalistas reinvestem, precisam encontrar meios adicionais de produção disponíveis no mercado. Os insumos de que necessitam são de dois tipos: os produtos intermediários já moldados pelo trabalho humano, que podem ser utilizados no processo de produção (como a energia e o tecido necessários para fazer um casaco) e máquinas e equipamentos de capital fixo, incluindo edifícios das fábricas e as infraestruturas físicas, como sistemas de transporte, canais e portos que permitem a atividade de produção (HARVEY, 2011, p. 46- 62).

Longe de pintar um quadro catastrófico no sentido de qualquer tipo de predição irresponsável, o que o autor tenta esclarecer é o complexo de particularidades que compõe um conjunto de contradições que caracteriza o capital. Isto posto, intensifica-se a contradição que se estabelece entre os limites (barreiras) naturais enquanto meio de produção e a necessidade inalienável de crescimento/expansão do capital. Não obstante, esta contradição é aqui considerada e ponderada também em relação à ampliação da produção de mais-valor relativo e as condições de vida do trabalhador, além de enfatizar as externalidades ambientais do processo de produção e de consumo.

\section{Metabolismo social e crise da relação ser humano-natureza}

As relações que os seres humanos realizam com a natureza são o ponto de partida para a concepção da ontologia do ser social e da crítica à economia política realizada por Karl Marx. Sua concepção de ontologia, para que fosse coerente com sua filosofia humanista, dialética e materialista, a natureza foi concebida como fonte dos meios de produção e como elemento fundamental do par dialético primordial que permite a concretização do intercâmbio material que constitui o ser humano. A dialética ser humano/natureza pensada de forma histórica foi o que tornou possível que Marx construísse sua concepção de ser humano, a qual norteou sua crítica à economia política. Por isso Marx sustentou que

O homem ao produzir só pode atuar como a própria natureza, isto é, mudando as formas da matéria. E mais. Neste trabalho de transformação é constantemente ajudado pelas forças naturais. $\mathrm{O}$ trabalho não é, por conseguinte, a única fonte de valores de uso que produz da riqueza material. Conforme diz William Petty, o trabalho é o pai, mas a terra é a mãe (MARX, 2008b, p. 65).

Dussel (2011) foi compelido a escrever um artigo com o objetivo de esclarecer como, de fato, Marx concebia a relação do ser humano com a natureza. O autor cita excertos de Marx que estabelecem um nexo dialético entre o trabalho e a natureza, sendo esta concomitantemente meio de produção, fonte 

o trabalho e este, por sua vez, a modifica com determinados fins. A natureza é fonte material de todas as riquezas naturais e o trabalho é dotado de riquezas específicas, mas não de toda a riqueza material. Sob o capitalismo, todavia, a relação ser humano/natureza encontra-se distorcida, pois sob esta forma de produção a sociedade se organiza a partir de um sistema de propriedade primordialmente excludente o que resulta numa relação social de dominação e de exploração.

Nos Manuscritos Econômico-filosóficos de 1844, Marx esclarece que a natureza natural e histórica do ser humano, constitui sua natureza genérica, ou da espécie:

A vida genérica, tanto do homem como do animal, consiste fisicamente, em primeiro
lugar, nisto: que o homem (tal qual o animal) vive da natureza inorgânica, e quanto mais
universal o homem é do que o animal, tanto mais universal é o domínio da natureza
inorgânica de que ele vive. Assim como as plantas, animais, pedras, ar, luz, etc., formam
teoricamente uma parte da consciência humana, em parte como objetos da ciência
natural, em parte como objetos de arte - sua natureza inorgânica, meio de vida
espiritual, que ele tem de preparar prioritariamente para a fruição e para a digestão -,
formam também praticamente uma parte da vida humana e da atividade humana.
Fisicamente o homem vive somente destes produtos da natureza, possam eles aparecer
na forma de alimentos, aquecimento, vestuário, habitação, etc. Praticamente, a
universalidade do homem aparece precisamente na universalidade que faz da natureza
inteira o seu corpo inorgânico, tanto na medida e que ela é um meio de vida imediato,
quanto na medida em que ela é o objeto/matéria e o instrumento de sua atividade vital.
A natureza é o corpo inorgânico do homem, a saber, a natureza enquanto ela mesma
não é corpo humano. O homem vive da natureza significa: a natureza é o seu corpo,
com o qual ele tem de ficar num processo contínuo para não morrer. Que a vida física e
mental do homem está interconectada com a natureza não tem outro sentido senão que
a natureza está interconectada consigo mesma, pois o homem é uma parte da natureza
(MARX, 2008a, p. 84).

Esse ser natural e histórico, tem como particularidade o trabalho, que é sua propriedade ativa e específica. Essa premissa, fundamental ao pensamento marxista é subvertida no capitalismo. Se o trabalho é único meio que incute valor à natureza, o capitalista, ao ser proprietário da força de trabalho, possui o próprio ser humano, pois detém sua propriedade ativa, sem a qual é impossível tornar-se humano; e mediatamente, possui também a natureza, pois esta é meio de produção e matéria do fabrico de valores de uso. Valores que já não possuem mais apenas este caráter, longe disso, enquanto mercadoria são mais valores de troca.

Com base na noção de metabolismo social, no qual ocorre a troca social de mercadoria e suas metamorfoses, o processo de trabalho medeia a interação do homem com os elementos naturais, os quais ao entrarem na esfera da produção serão objetos de trabalho e matérias-primas. Conforme esclarece Foster (2005), Marx introduziu o conceito de metabolismo social que é central à sua análise crítica da economia política, e que por sua vez, deriva do próprio processo de trabalho, que é

a atividade orientada a um fim para produzir valores de uso, apropriação do natural para satisfazer as necessidades humanas, condição universal do metabolismo entre o homem e a natureza, condição natural eterna da vida humana e, portanto, independente de qualquer forma dessa vida, sendo antes igualmente comum a todas as suas formas sociais (MARX, 1996, p. 303). 
A ruptura ou falha metabólica entre sociedade e natureza ocorreria justamente a partir de graves entraves ao metabolismo social, o qual é, por sua vez, dependente dos elementos e processos naturais. De modo que

não é a unidade do ser humano vivo e ativo com as condições naturais, inorgânicas, do seu metabolismo com a natureza e, em consequência, a sua apropriação da natureza que precisa de explicação ou é resultado de um processo histórico, mas a separação entre essas condições inorgânicas da existência humana e essa existência ativa, uma separação que só está posta por completo na relação entre trabalho assalariado e capital (MARX, 2011, p. 648).

Ou seja, o metabolismo social, se utiliza de matéria, energia e recursos naturais a partir do metabolismo universal maior com a natureza, contudo, as contradições e a tendência inexorável de crescimento quantitativo crematístico do capital leva a uma falha metabólica, comprometendo as bases ecológicas da existência humana (FOSTER, 2015).

O trabalho e sua consequente produção social de riqueza torna-se impossível sob o capitalismo, pois a apropriação privada dos meios de produção e a divisão social do trabalho, além de manter o trabalhador constantemente dependente do capitalista, a própria produção tem como fim o acúmulo nas mãos de poucos privilegiados. E isto tende a ampliar-se com o aumento da concorrência, com as crises cíclicas, com a escassez/degradação dos recursos naturais e com o acirramento das contradições do capital. Não é, neste aspecto, uma questão puramente ética, mas de lógica: o capitalismo, para sobreviver, para manter-se como eixo central da base material de acesso/acumulação dos meios e relações de produção, deve funcionar desta forma, destarte, estaríamos falando de outro modo de produção.

O capital constitui-se historicamente como uma inversão ontológica entre fins e meios. O trabalhador enquanto mercadoria encontra-se no mercado sob os auspícios dos capitalistas, e a mercadoria mais valiosa, o trabalho, encontra-se à disposição do mercado para produzir outras mercadorias dotadas de valores de troca que passam a subsumir seus respectivos valores de uso. A humanidade acaba por existir para produzir em função dos excedentes que alimentam uma taxa continua de crescimento, que é o que permite sobrevida ao capital. Não se produz para humanizar-se, nem para o bem estar social, mas para manter uma taxa de crescimento constante. Retomando Dussel, é isto que qualifica o pensamento marxista, sua especificidade não-antropocêntrica e não economicista, já que em sua teoria do valor/trabalho está incutido um valor ecológico, pois este valor é a conexão da relação dialética entre o valor de uso (natural) e o valor de troca produzido pelo trabalho.

Isto esclarecido, faz-se mister explicitar o cerne das discussões Ecossocialistas: "o homem constrói sua história ao transformar a sociedade, a natureza e a si mesmo, mas não existem limites impostos pela natureza. Portanto, a natureza é concebida como um conjunto de recursos que podem ser utilizados (ALTVATER, 2006, p. 341)”. Os críticos do Ecossocialismo, por estranho que pareça, acusam o próprio Marx de sustentar esta premissa e utilizá-la como fundamento para suas pesquisas em economia política. Na verdade, segundo Elmar Altvater, esta concepção provém desde Francis Bacon, John Locke e Adam Smith. O próprio David Ricardo já a criticara e reconhecia a natureza como um fator limitante à produção material das economias nacionais. Marx progride em relação a Ricardo, e a partir da sua 
perspectiva histórica, ressalta que as leis do movimento do acúmulo capitalista são moldadas pelas contradições sociais e pelos limites impostos pela natureza. Essa perspectiva enfatiza os meios de produção (recursos naturais e força de trabalho) como elementos cada vez mais importantes na história do capitalismo, em especial, a partir do capitalismo industrial, o qual exigiu uma forma de circulação ampliada.

O problema dos limites ecológico-naturais à produção capitalista é a contradição existente entre uma taxa de crescimento constante, o que exige produção e consumo crescentes ou no mínimo estáveis por certo tempo. Mesmo quando há um limite à realização do capital (consumo), o capitalista tenta compensar na produção ou na manipulação no mercado de valores. Este movimento pendular degrada a natureza seja no âmbito da extração de materiais, seja no âmbito da geração de resíduos/poluição. O problema se intensifica quando se considera que:

A conversão de uma parte do lucro de ontem em capital novo depende, portanto, da disponibilidade de uma quantidade maior de meios de produção, bem como de uma quantidade crescente de bens básicos para o sustento dos trabalhadores adicionais a serem empregados. O problema é organizar o fornecimento de insumos materiais, de modo a sustentar continuamente o fluxo de capital (HARVEY, 2011, p. 41).

Os limites da natureza enquanto meio de produção são reais e "esgotamento e a degradação da terra e dos chamados recursos naturais não fazem mais sentido no longo prazo do que a destruição dos poderes coletivos do trabalho, pois ambos estão na raiz da produção de toda a riqueza (HARVEY, 2011, p. 66)".

Analisando dialeticamente: os limites naturais, o trabalho alienado e as relações de classe construídas sob o capitalismo aparecem como corresponsáveis pela pobreza e pela precarização do trabalho. Em consequência, essa relação torna-se cada vez mais dramática na medida em que o espaço é expropriado e divididos na forma de propriedade privada, os recursos vão se tornando cada vez mais escassos e poluídos, as alterações climáticas ampliam seus efeitos, as florestas e hábitats são destruídos e fragmentados. A natureza, por sua vez, pode vir a tensionar as relações sociais e o sistema de produção, pois tornam-se mais caros e mais restritos a poucos detentores de poder social para explorá-los. Nas próximas páginas veremos que o problema é ainda mais complexo.

Mesmo a despeito dos avanços da ciência e da tecnologia, é importante salientar que para Marx a natureza não possui uma capacidade de manutenção ilimitada, como explica Foladori (2001), a teorização marxiana no que se refere à relação sociedade/natureza abre perspectiva para ponderarmos as repercussões dos usos da tecnologia, e da relativa imprevisibilidade que decorre do desenvolvimento econômico capitalista em relação aos dos limites naturais. Não obstante, a aplicação do seu método na análise da economia política proporcionou a análise dos impactos da produção capitalista sobre a natureza.

Na verdade, a contradição entre capital e natureza já fora bem descrita e sustentada pelo próprio Marx, como categoria fundamental para explicar o capitalismo. Foster (2005) explica que os conceitos de metabolismo social e de fenda metabólica na interação entre o homem e a terra foi uma forma que Marx encontrou para explicar como a natureza engendra o metabolismo social. E reciprocamente, o capitalismo 
(como no caso do agronegócio, por exemplo) impede qualquer aplicação racional (ou sustentável) da ciência no manejo do solo, apesar de toda ciência e tecnologia, a recomposição cíclica do solo torna-se inviável. Trata-se do metabolismo como sinônimo de troca material relativa "à noção dos processos estruturados de crescimento e de decadência biológica englobados pelo termo metabolismo (FOSTER, 2005, p. 221)". Importante ressaltar que a acepção de falha metabólica é derivada da forma com que o trabalho, que é o meio do ser humano dispõe de mediar sua atividade com a natureza, veio a se concretizar sob o capitalismo.

A falha metabólica só se concretiza por meio da alienação promovida pelas relações de trabalho alienadas historicamente definidas na intensificação da divisão social do trabalho e sob o trabalho assalariado em sua relação com o capital. Foster (2005) esclarece que a ação regulatória da sociedade em relação à natureza depende da capacidade humana em afetar os processos naturais, mas, por conseguinte, as condições não deixam de ser "impostas" pela natureza. A produção econômica humana relaciona-se reciprocamente com a troca material derivada do fluxo circular ecológico.

Um erro fundamental que ambientalistas e ecologistas verdistas normalmente incorrem é de realizar uma crítica ferrenha (porém limitada no que se refere à compreensão das questões socioambientais) ao consumo, desdenhando a esfera da produção. Ora, dialeticamente, o consumo engendra a produção e vice-versa. Esta relação dialética foi genialmente explicitada por Marx:

O consumo é também imediatamente produção, do mesmo modo que na natureza o consumo de elementos e das substâncias químicas é produção nas plantas. Parece bastante claro que na alimentação, por exemplo, que é uma forma de consumo, o homem faz seu próprio corpo; mas é igualmente certo em qualquer outro gênero de consumo que, de um modo ou de outro, o homem produza. Esta é a produção consumidora. (...) A produção é, pois, imediatamente consumo; o consumo é, imediatamente, produção. Cada qual imediatamente o seu contrário. Ao mesmo tempo, opera-se um movimento mediador entre ambos. A produção é mediadora do consumo, cujos materiais cria e sem os quais não teria objeto. Mas consumo é também imediatamente produção enquanto procura para os produtos o sujeito para qual são produtos (MARX, 2007, pp. 244-245).

Ou seja, não tem sentido falar estritamente do consumo. É óbvio que a atividade consumidora gera resíduos que vão gerar impactos socioambientais, mas tomado de forma isolada, a crítica apenas ao consumismo acaba por culpabilizar somente o indivíduo, escondendo parte essencial do processo, a extração de matérias-primas e combustíveis fósseis, a produção (considerando as corporações, é claro), a circulação e a organização social derivada. A mercadoria é resolvida (se realiza) no consumo, mas também é o resultado imediato do processo de produção. "O consumo produz a produção porque cria a necessidade de uma nova produção, ou seja, o móvel ideal, interno da produção, que é seu pressuposto (MARX, 2007, p. 245)". Mas a produção, por sua vez, fornece o objeto do consumo, fornece seu material, produzindo seu consumo e o modo de consumo. Por isso fala-se em consumismo. E Marx assevera: "A fome é fome, mas fome que se satisfaz com carne cozida, que se come por meio de uma faca ou de um garfo, é uma fome muito distinta da que devora carne crua, com a ajuda das mãos, unhas e dentes (MARX, 2007, p. 246)". 
Em suma, a produção ao engendrar o consumo produz seu objeto e também seus consumidores. A produção cria, pois, os consumidores, produz os objetos e os sujeitos para este objeto. Não esqueçamos que é na esfera do consumo que se realiza o valor de troca. É o que impulsiona, mas, novamente, a forma de consumo é determinada pela produção. Assim: "A produção engendra, portanto, o consumo: 1 - fornecendo-lhe os materiais; 2 - determinando seu modo de consumo; 3 - excitando no consumidor a necessidade dos produtos que a produção estabeleceu como objetos (MARX, 2007, p. 247)" . Além disso, é bom que se diga, é na produção e não necessariamente na circulação/consumo que a extração de mais valor acontece, por meio da exploração do trabalho alheio, do trabalho assalariado, por meio dessa mercadoria especial chamada força de trabalho.

Eis aqui um bom exemplo da aplicação da dialética marxiana na compreensão de um objeto em suas múltiplas formas de objetivação. Se é dado que se compreenda a dialética entre relação e consumo, Chasin (Maceió, s/d, p. 02) esclarece que "o sujeito pode conhecer a totalidade do objeto, mais do que isto, ele deve conhecer a totalidade do objeto, ainda mais, conhecer é só conhecer quando a totalidade do objeto é compreendida". Este trecho é aqui citado, pois ao ambientalista ou ao ecologista crítico-dialético é limitante se ater em análises contingentes de um processo histórico complexo como o capitalismo. Ainda mais no que concerne à compreensão dos impactos gerados na esfera da extração de materiais (mineração, por exemplo), da produção de mercadorias, até a produção de resíduos gerados na esfera da produção e do consumo. Estas são particularidades que compõem uma totalidade dialeticamente coordenada: a forma capitalista de produção e circulação de mercadorias, que forma uma totalidade maior, mais geral, que tem a ver com a mediação de primeira ordem caracterizada pela relação do ser humano com a natureza.

Aqui sobressai outra contradição importante do capital que reúne a forma de produção (base material produtiva) e a divisão social do trabalho. O capital não consegue aboli-la, ao contrário, desenvolve e intensifica a divisão social do trabalho, numa sociedade já marcada pela apropriação privada dos meios de produção. A produção é estimulada, mas a sociedade não se desenvolve, pois quanto maior é a produção de riqueza, mais ela se concentra nas mãos de poucos indivíduos, o que limita a produção. A repercussão desta contradição para o trabalhador é que o salário se caracteriza pela taxa mais baixa necessária para a subsistência deste e de sua família; além disso, a procura por força de trabalho por parte do capitalista regula a constituição dos seres humanos, assim como qualquer mercadoria. Se a oferta de trabalho é muito maior do que a procura, os salários baixam e então grande parte dos trabalhadores entra em situação de pauperismo. O trabalhador torna-se uma mercadoria deixada à sorte daquele que se interesse por ele. Numa sociedade na qual a divisão de trabalho é intensa, fica impossível ao trabalhador dar ao seu trabalho outra direção, cabe-lhe uma situação subalterna ao capitalista. Além de lutar pelos pela sua sobrevivência tem ainda que lutar pela aquisição de trabalho (MARX, 2008b).

É fundamental que se compreenda essa dinâmica interna ao capital para que se possa dialetizar sobre a forma intensiva com que a nossa sociedade vem incorporando a natureza de forma a gerar tensões de grande magnitude e interferindo decisivamente em processos ecológicos. O capitalismo incorpora a natureza pelos processos de expropriação-apropriação-mercadorização. O despossessamento (expropriação) por meio 

particularmente comum com que corporações têm garantido sua permanência e expansão. A mercadorização da natureza é o processo que corresponde à "articulação entre a natureza e o processo de trabalho, em que este introduz o trabalho assalariado como agente transformador da natureza numa matéria qualitativa diferente, portadora de uma utilidade social e, sobretudo, de valor de troca (AGUIAR; BASTOS; 2012, p. 86)".

Assim, a compreensão da relação ser humano/natureza requer um embasamento históricosocial no sentido de se explicitar as nuances históricas que levaram a cabo a alienação do ser humano ante a natureza. Portanto,

(...) as relações com o mundo externo cada vez mais são mediadas por instrumentos e coisas previamente produzidos -, ao mesmo tempo que em seu interior os elementos que a compõem se separam em uma progressiva divisão social do trabalho. Assim, o que requer explicação, escreve Marx, não é a unidade do ser humano com a natureza, pois isso é parte da natureza física e química, mas o que se deve explicar é o processo histórico por meio do qual se separa - aliena-se - a existência humana dos condicionantes naturais necessários para reproduzir-se (FOLADORI, 2001, p. 107).

A partir dessa noção, da qual se abstrai que a existência humana advém da sua relação alienada com a natureza, no que tange à constituição histórica da humanidade sob o capitalismo, torna-se possível compreender que os seres humanos são entes naturais e históricos, que por meio do trabalho, transforma a natureza e as suas próprias condições de existência, ainda que de forma alienada, sob o capitalismo.

A categoria de contradição dialética contribui para que se compreendam as mútuas interações entre complexos da realidade e como esta define o condicionamento estrutural da relação sociedade/natureza. Como explicitado por Harvey (2016), as contradições do capital são campos reais em que forças, aparentemente opostas, presentes no mesmo tempo/espaço definem-se mutuamente. Não necessariamente resolvem-se, frequentemente deslocam-se no espaço/tempo, ou intensificam-se, gerando crises. Assim, o autor listou dezessete contradições do capital e classificou-as em três grupos: 1) as contradicões fundamentais: valor de uso e valor de troca; o valor parcial do trabalho e sua representação pelo dinheiro; propriedade privada e estado capitalista; apropriação privada e riqueza comum; capital e trabalho; unidade contraditória entre produção e realização; 2) as contradições mutáveis: tecnologia, trabalho e descartabilidade humana; divisões do trabalho; monopólio de competição - centralização e descentralização; desenvolvimentos geográficos desiguais e produção do espaço; disparidade de riqueza e renda; reprodução social; liberdade e dominação; 3) as contradicões perigosas: crescimento exponencial infinito; a relação do capital com a natureza; a revolta da natureza humana - alienação universal.

Logicamente, essas contradições interagem mutuamente entre si. A contradição da relação do capital com a natureza, a qual foi classificada como perigosa por Harvey, quando relacionada com outra contradição potencialmente letal, a do crescimento exponencial ilimitado, a relação que o capital realiza com a natureza ganha outra dimensão. O capital deve crescer, por regra, a uma taxa composta de 3\% ao ano, quando o crescimento fica abaixo disso, isto indica recessão, com o passar do tempo, depressão. Um planeta com recursos e capacidade de suporte limitados não consegue dar conta desta taxa constante de 
crescimento. Outras contradições sobre as quais podemos ponderar são a dominação/expropriação, a apropriação privada sobre os bens comuns e a descartabilidade humana. Estas contradições concretizaram-se numa "liberdade" para pilhar recursos de populações tradicionais locais e populações indígenas, extrapolando a resiliência dos ecossistemas, poluindo o solo/subsolo, o ar, cursos de água e levando à extinção a biodiversidade.

Sob o capital, a natureza e seus elementos e funções ecossistêmicas são "agentes ativos em todos os pontos do processo de acumulação do capital. O fluxo monetário é uma variável ecológica, e a transferência de nutrientes através de um ecossistema também deve constituir um fluxo de valor (HARVEY, 2016, p. 230)". Isto quer dizer que a natureza encontra-se internalizada no processo de produção, na circulação, acumulação, e realização do capital; sob a forma de mais-valor. O "ecossistema” que o capital tornou-se funciona por meio da privatização, pela poluição, destruição de hábitats e de ecossistemas e pela compensação ambiental. A contradição entre o capital e a natureza é perigosa e/ou potencialmente fatal, pois:

O capital vê necessariamente a natureza - e devo destacar que ela poderia ser e é considerada de um modo muito diferente dentro do capitalismo como um todo - como uma grande reserva de valores em potenciais (de processos e coisas) que podem ser usados direta ou indiretamente (por meio da tecnologia) na produção de valores das mercadorias. A natureza é um "imenso posto de gasolina” (para citar Heidegger), e os valores de uso naturais são monetizados, capitalizados, comercializados e trocados como mercadorias. A natureza é fracionada e dividida na forma de direitos de propriedade garantidos pelo Estado (HARVEY, 2016, p. 232).

De fato, o capital apropria-se da natureza e a transforma num recurso que será parte essencial na geração de mais-valor, e sob o capitalismo financeiro, a natureza será monetizada e comercializada. Sob a forma de mercadoria, seu valor de uso praticamente (ou aparentemente) desaparece. Todavia, a magnitude e a complexidade dos problemas ambientais nos impelem a uma abstração um pouco mais cuidadosa. Daî decorre o ponto principal de discussão entre os Ecossocialistas: até que ponto o capital de fato internaliza a natureza? Pode-se inferir, portanto, que uma crise ecológica conduz necessariamente a uma crise do capitalismo?

Veremos a seguir que essas questões geraram discussões acirradas entre os chamados Ecossocialistas de primeira geração, em geral defensores das teorizações de James O’OConnor, fundador da revista Capitalism, Nature, Socialism; e os Ecossocialistas de segunda geração, representados proeminentemente por Economistas Ecológicos americanos, como Brent Clark, Paul Burkett e Johh B. Foster, atual editor-chefe da revista Montly Review ${ }^{10}$.

\section{$A$ "segunda contradição" e as discussões entre os Ecossocialistas}

Em 1988, James O’Connor, na introdução da primeira edição da revista Capitalism, Nature, Socialism, sustentou que o capitalismo evolui sob duas contradições básicas: a primeira contradição entre a produção necessariamente crescente de mercadorias e as forças de produção. Segundo ele, tal contradição 

onde as forças de produção entram em contradição com as relações de produção existentes. Seu corolário é que em tempo de crescimento, o capitalista acumula e concentra riqueza, o que resulta contraditoriamente na pauperização e degradação humana. Em tempos de crises de superprodução se dá uma queda acentuada na realização das mercadorias devido à queda no consumo, que provém diretamente da pauperização do trabalhador. Já a "segunda contradição", chamada por O'Connor de "Lei geral absoluta da degradação ambiental" se expressa pela tendência ao esgotamento e poluição dos recursos naturais, destruição de hábitats e extinção da biodiversidade (condições de produção) entra em contradição com a acumulação de riqueza derivada e do aumento na produção de excedentes. Assim, o O marxismo ecológico tem suas bases teóricas estabelecidas.

Como bem esclarece Dantas (2021), o modelo da segunda contradição de James O'Connor sustenta que a crise ambiental é também econômica, mas que possui sua gênese na destruição do meio ambiente. As margens de lucros seriam gradativamente solapadas em função do deplecionamento crescente das condições de produção. Com as margens de lucro comprometidas, o capitalista seria obrigado a intensificar e ampliar espacialmente a produção, que levaria a mais produção de resíduos e poluição. Porém, O'Connor afirmou que a partir de um dado momento a segunda contradição se sobreporia à primeira contradição, a qual se expressa pela tendência inexorável do descompasso entre a superprodução que resulta num déficit de realização (crise de realização) gerado pela taxa de exploração e degradação da classe trabalhadora.

Foster (1992) fez uma síntese das teorizações de O'Connor até então, cuja produção teórica considerou como fundamental para a compreensão de que o aumento da produção/concentração de riqueza gera demandas ecológicas, levando à degradação ambiental, podendo levar, por seu turno, a custos à própria economia capitalista. Todavia, o próprio Foster, passou a questionar se de fato os custos ecológicos são internalizados pelo capital, gerando crises. Se fosse esse o caso, de que forma e até que ponto a degradação ambiental seria internalizada pelo capital? Em especial, questionou a validade da afirmação feita por O'Connor, de que, com o tempo, a segunda contradição se sobrepunha à primeira. O problema é que não há evidências históricas de que a destruição da natureza (meios e processos de produção) se traduz necessariamente em crises econômicas, no sentido de internalização dos danos ambientais (externalidades ambientais). O principal problema com a tese da segunda contradição pode ser assim compreendido:

Todo o impulso da concepção de 'segunda contradição' é que uma vez que os danos ecológicos são traduzidos em uma crise econômica para o capitalismo, um mecanismo de feedback é colocado em jogo, tanto diretamente através da tentativa do capital de conter os custos crescentes de produção associados ao enfraquecimento de suas condições de produção, quanto indiretamente através de tentativas de movimentos sociais para forçar o sistema a internalizar as externalidades, ou seja, pagar os custos sociais e ambientais que o capital tem procurado externalizar - empurrando-o assim na direção de uma produção mais ecologicamente sustentável. A presunção óbvia é que uma crise econômica decorrente de causas ecológicas constitui uma oportunidade para a esquerda, uma onda de salto por assim dizer - uma onda que lhe permite construir 
uma aliança entre um movimento trabalhista de classe e os novos movimentos sociais. É minha alegação, no entanto, que não existe tal mecanismo de retroalimentação pelo menos para o capitalismo como um todo. Como os verdes alemães disseram, o sistema reconhecerá que o dinheiro só não pode ser comido quando a última árvore foi cortada - e não antes. Não devemos subestimar a capacidade do capitalismo de se acumular em meio à destruição ecológica mais flagrante, lucrar com a degradação ambiental (por exemplo, através do crescimento da indústria de gestão de resíduos), e continuar a destruir a terra a ponto de não haver retorno - tanto para a sociedade humana quanto para a maioria das espécies vivas do mundo. Em outras palavras, os perigos de um aprofundamento do problema ecológico são ainda mais graves porque o sistema não possui um mecanismo regulatório interno (ou externo) que o faça se reorganizar. Não há contrapartida ecológica para o ciclo de negócios (FOSTER, 2021, p. 04)

Mesmo considerando os limites da tese da segunda contradição, O’Connor contribuiu decisivamente para a compreensão de como a crise ecológica se relaciona com o processo de desenvolvimento desigual e combinado, conforme teorizado por Paul Baran, na década de 1950.

O desenvolvimento desigual é uma consequência inerente à acumulação do capital. A sociedade de classes passa a vivenciar as desigualdades sociais e econômicas derivadas da maximização da concentração de renda. O desenvolvimento combinado ocorre no âmbito geográfico no qual a expansão do capital para países periféricos, associados a novas tecnologias e níveis maiores de divisão do trabalho, acaba gerando grande exploração do trabalho e pauperização nesses países, tidos como fornecedores de matéria-prima e mão de obra barata. A combinação de ambos os tipos de desenvolvimento acaba por aumentar o número de áreas degradas de mineração, poluição e escassez de recursos, dos meios de produção. Assim:

primeiro o desenvolvimento desigual e as diferentes formas de contaminação; como também, o desenvolvimento desigual e o esgotamento de recursos; depois, o desenvolvimento combinado e a contaminação e o esgotamento de recursos; além da forma com que os recursos estão sendo esgotados de maneira indireta devido à contaminação e, finalmente, a forma com que a contaminação resulta indiretamente no esgotamento dos recursos (O’CONNOR, 2003, p. 13)

Trata-se, na realidade, de considerar a relação de exploração entre os países centrais e os país es periféricos do capital. Além de relacionar como a relação produção-consumo, engendra a forma de produção intensificada, perdulária e planejada com vista à obsolescência e o modo de consumo que é exportado das nações centrais às periféricas. Esses aspectos contingentes do metabolismo entre sociedade e natureza com base na teoria do crescimento desigual e combinado foi brilhantemente estabelecido, da seguinte maneira:

O desenvolvimento desigual não se reduz à concentração da produção industrial, ao comércio, a população típicas das zonas desenvolvidas, mas se estende à concentração da agricultura e à extração de matérias-primas nas zonas subdesenvolvidas nas quais o 'metabolismo básico' entre as pessoas e a natureza também é perturbado. A desflorestação, as secas, as inundações, o assoreamento dos rios que inevitavelmente se relacionam, foram elementos fundamentais à era dourada do capitalismo - uma era que viu a produção massiva de bens, mas também o aumento e intensificação de secas, de inundações e da fome (O'CONNOR, 2003, p. 15). 
A crise socioambiental derivada desse tipo de desenvolvimento típico do capitalismo monopolista, descrita sob termos de degradação da natureza, pode assumir um caráter distintivo, contendo causas estruturais e causas conjunturais. Por exemplo:

A causa direta da contaminação atmosférica urbana pode ser o transporte de veículos, mas a causa estrutural é o sistema de transporte baseado no automóvel individual. A causa direta da contaminação do solo e da água pode ser o uso de agrotóxicos, mas a causa estrutural pode ter como raiz o sistema de produção para o mercado que força o aumento dos rendimentos menosprezando a sustentabilidade ecológica de longo prazo. Em qualquer caso, se não se conhecem as causas estruturais, as medidas de política ambiental podem não ser muito efetivas (FOLADORI, 2005, p. 02).

Começa a ficar claro, que talvez seja ineficaz atuar na gestão ambiental e no enfrentamento da crise socioambiental se não dialetizarmos causas conjunturais e causas estruturais, e ir além: deve-se procurar compreender as tendências históricas estruturais. Persistindo em soluções contingentes tuteladas sob a lógica do capital, prevalecerá o fundamento da vantagem econômica (com base na acumulação, centralização e concentração ampliada do capital), seja no tocante ao uso intensivo dos recursos naturais disponíveis, levando a exaustão, seja nos processos de poluição/contaminação, seja no que se refere ao tratamento de resíduos e efluentes. Se o lucro aumentar, o ciclo de rotação se intensifica e as mercadorias serão produzidas de forma cada vez mais célere, aumentando, por conseguinte, os impactos socioambientais; conforme se tem observado, por exemplo, durante a extração de minerais, com a produção de resíduos e a poluição ao longo da cadeia de produção-circulação-consumo. Portando, não basta administrar as mazelas das relações reprodutoras do capital, é necessário e urgente à sua superação.

A cultura do individualismo pensada no âmbito da relação entre produção/demanda/escassez de recursos põe no centro da discussão a produção dos sujeitos sociais que agem individual e egoisticamente a partir de um sistema que depende da natureza e dos seus limites. Segundo Altvater (2006), na análise da economia política marxiana não cabe economicismos ou reducionismos antropocêntricos, pois a análise parte da perspectiva de totalidade sociedade-ser humano-natureza concretizada pelas transformações de matéria e energia viabilizadas pelo trabalho sob um dado modo de produção. A natureza é mais do que apenas o prolongamento do corpo do homem, o meio da minha realização, o ser humano em sua atividade constitui-se a partir do seu metabolismo com a natureza, sendo que neste processo ambos se confundem, num só corpo inorgânico/orgânico: a natureza relaciona-se consigo mesma. Os produtos da atividade humana, como uma habitação, são natureza transmutada por meio do trabalho. A questão que é foco da crítica Ecossocialista, portanto, é a forma histórica que o trabalho alienado assume sob o modo de produção capitalista.

Ricardo Antunes, ao escrever a introdução do livro A crise estrutural do capital de Ístvan Mészáros, chama atenção para o fato de que o capital, por não ter limites para sua expansão, torna-se altamente destrutivo e potencialmente incontrolável. E acrescenta: “produção e consumo supérfluos acabam gerando a corrosão do trabalho, com sua consequente precarização e desemprego estrutural, além de imputar uma destruição da natureza em escala global jamais vista anteriormente (MÉSZÁROS, 2009 p. 11)". O filósofo húngaro chama a atenção para um aspecto fundamental: a taxa de utilização decrescente 
do valor de uso das mercadorias. O que pode ser considerado um efeito esperado da produção eminentemente voltada à produção de valores de troca, isto gera efeitos estruturais quando relacionados ao tempo de vida útil das mercadorias numa produção direcionada para a autorreprodução do capital e não ao atendimento a necessidades humanas genuinas. Considerando a centralidade da utilização dos recursos naturais, a geração de resíduos e a poluição, uma via que certamente contribuirá para o colapso do sistema é compreendida por meio da explicitação de outra contradição do sistema:

Outra contradição básica do sistema capitalista de controle é que ele não pode separar 'avanço' de destruição, nem 'progresso' de desperdício - ainda que as resultantes sejam catastróficas. Quanto mais o sistema destrava os poderes da destrutividade, mais libera os poderes da destruição; e quanto mais dilata o volume da produção tanto mais tem de sepultar tudo sob montanhas de lixo asfixiante. O conceito de economia é radicalmente incomparável com a 'economia' da produção do capital, que necessariamente causa um duplo malefício, primeiro por usar com desperdício voraz os limitados recursos do nosso planeta, o que é posteriormente agravado pela poluição e pelo envenenamento do meio ambiente humano, decorrente da produção e massa de lixo e efluentes (MÉSZÁROS, 2009, p. 73).

Destrutividade e desperdício são especificidades da medição de primeira ordem que o ser humano mantém com a natureza. Contudo, considerando a divisão do trabalho, a propriedade privada e a alienação do trabalho no capitalismo -, o metabolismo ser humano/natureza passa a ser potencialmente limitadora da produção nos moldes capitalista, já que afeta diretamente a objetivação do próprio ser social. Como, portanto, a produção capitalista avançaria por meio da destruição/desperdício dos meios de produção e da precarização do trabalho? Quais suas repercussões sobre a própria produção e sobre os meios de sobrevivência dos seres humanos? Tais questões têm sido respondidas de maneira relativamente inovadora por gerações de Ecossocialistas, sem prescindir do pensamento marxiano fundamental.

\section{Da falha metabólica à espiral da destruição ecológica}

A crise socioambiental é um fato que tem ocorrido não só nas zonas produtoras de matérias primas dos países periféricos do capital - danos ambientais são espraiados globalmente por meio da troca de mercadorias e da acumulação de capital, o que leva também à produção de resíduos e a contaminação -, assim como a poluição dos solos, da água e do ar, a depleção da biodiversidade; seja por meio da extração mineral e/ou pela utilização de combustíveis fósseis; são parte do mesmo processo histórico.

Considerando o âmbito macroeconômico, faz-se mister retomar o conceito de metabolismo social, como descrito por Marx e retomado por Foster. Em O Capital, Marx definia este conceito como o processo entre o homem e a natureza, por meio do qual o homem medeia e controla o metabolismo entre ele mesmo e a natureza. É por meio deste processo que o ser humano cria as condições de produção, mas Marx também explica que é somente por meio das mediações sociais que os seres humanos acessam os meios de produção. Os limites naturais são parte importante das categorias analisadas por Marx, em especial quando ele teorizou sobre a renda da terra e o declínio da fertilidade natural do solo em função da 
quebra do ciclo de materiais e a limitação da oferta de fertilizantes, tanto naturais quanto sintéticos. Desta forma:

Uma parte central do argumento de Marx era a tese de que o caráter inerente da agricultura de larga escala no capitalismo impede qualquer aplicação verdadeiramente racional da nova ciência do manejo do solo. Apesar de todo o desenvolvimento científico e tecnológico da agricultura, o capital era incapaz de manter condições necessárias à reciclagem dos elementos constitutivos do solo (FOSTER, 2005, p. 221).

Foster (2005) afirma que em Glosas a Adolph Wagner, Marx se referia à produção de troca material entre o homem e a natureza como um processo natural e histórico. Refere-se também à circulação de mercadorias como sendo também designada pela circulação ecossistêmica de materiais, estabelecendo, desta forma, que o fluxo da economia está relacionado dialeticamente à troca material (ou ao fluxo circular ecológico), assim estabelecendo a interação metabólica entre o ser humano e a natureza. Ou seja, o conceito de metabolismo social e de falha metabólica permitem que se compreenda a relação entre as categorias de troca material e de ação regulatória imprimida pela sociedade, sintetizando as condições naturais e a ação humana sobre estes mesmos processos naturais. Conforme o próprio Marx:

o homem está em relação com as coisas do mundo externo como meios para a satisfação de suas carências. Mas de modo algum os homens começam 'estando nessa relação teórica com as coisas do mundo externo'. Eles começam, como todo animal, comendo, bebendo etc., ou seja, não 'estando' em uma relação, mas sim se comportando ativamente, apoderando-se pela ação de certas coisas do mundo externo, e assim satisfazendo sua carência (eles começam, portanto, com a produção). Pela repetição desse processo, a propriedade dessas coisas de 'satisfazer suas carências' se inculca em seu cérebro e os homens, como animais, também aprendem a distinguir 'teoricamente', de todas as outras coisas, as coisas externas que servem à satisfação de suas carências. Em certo estágio de desenvolvimento, depois de, nesse ínterim, também suas carências e as atividades que as satisfazem terem aumentado e continuado a se desenvolver, eles também batizarão com a linguagem toda a classe dessas coisas distinguidas de acordo com a experiência do restante do mundo externo. Isso sucede necessariamente, pois, num processo de produção - isto é, no processo de apropriação dessas coisas -, eles estão continuamente em lide laborativa entre si e com essas coisas e logo têm de se bater em luta uns com os outros por elas (MARX, 2017b, p. 259).

Neste processo de apropriação das "coisas da natureza", a contradição entre o capital e a natureza (condições de produção capitalista) pode ser compreendida por meio da elucidação da relação entre a apropriação privada dos meios de produção, a apropriação primitiva, a intensificação da produção de excedentes e a escassez/limites de recursos, incluindo a subliminar capacidade de manutenção/recuperação da natureza e tendo como base a resiliência dos ecossistemas.

O metabolismo entre o ser humano e a natureza sob o capitalismo, considerando a teoria marxista de renda da terra, pode ser compreendido como um processo que de forma integrada, depleciona tanto a terra (como simbologia da natureza) quanto o ser humano (o detentor do trabalho enquanto sua propriedade especificamente ativa). Portanto:

o modo de produção capitalista perturba a interação metabólica entre o homem e a terra, ou seja, impede o retorno ao solo dos seus elementos constitutivos consumidos pelo homem, sob a forma de alimentos e vestuário; daí que impede o funcionamento da eterna condição natural para a fertilidade do solo (FOSTER; MAGDOFF, 1998, p. 04). 
O metabolismo que o ser humano realiza com a natureza torna-se limitado e limitante do processo de produção capitalista. A fertilidade do solo, naturalmente limitada, tensiona a produção para que se desenvolvam tecnologias, fertilizantes e agrotóxicos com vistas ao aumento de produção em larga escala e curto espaço de tempo. Esse processo conduz ao aumento os custos da produção, o qual é refletido em baixos salários, desemprego e pauperização. Dessa forma a precarização do trabalho se associa com a degradação do solo, pois

na agricultura moderna, como na indústria urbana, o aumento da força produtiva e a maior mobilização do trabalho obtêm-se com a devastação e a ruína física da força de trabalho. E todo progresso da agricultura capitalista significa progresso na arte de despojar não só o trabalhador mas também o solo; e todo aumento de fertilidade da terra num tempo dado significa esgotamento mais rápido das fontes duradouras dessa fertilidade. Quanto mais se apoia na indústria moderna o desenvolvimento de um país, como é o caso dos Estados Unidos, mais rápido é esse processo de destruição. A produção capitalista, portanto, só desenvolve a técnica e a combinação do processo social de produção, exaurindo as fontes originais de toda riqueza: a terra e o trabalhador (MARX, 1980, p. 578-579).

O desenvolvimento histórico dessa contradição tem levado à escassez dos recursos naturais, que por meio de superexploração, estão levando os ecossistemas aos limites de resiliência. Isto ajudou a promover, dentre outros fatores, o capital à sua fase monopolista, por meio da regulamentação da escassez e dos preços. Este processo foi especialmente perceptível na ascensão da indústria do carvão, do petróleo e da madeira.

Se por um lado o conceito de falha metabólica explica como vem se constituindo historicamente a relação entre o ser humano e a natureza sob o capitalismo; por outro lado, considerando a forma de produção de mais-valor e as crises de superprodução (de realização) típicas do capital, a análise ecomarxista não deixa de centralizar em sua análise a contradição entre as barreiras físicas (naturais) e as crises do valor no capitalismo. Combinado às novas tecnologias produtivas, o capital, em sua capacidade adaptativa, amplia a exploração dos bens naturais coletivos, ao mesmo tempo em que cria excedente de força de trabalho e novos mercados. Em um cenário de desenvolvimento desigual, as diferentes formas de contaminação e de escassez de recursos relacionam-se reciprocamente. Considerando a forma de esgotamento dos recursos e a contaminação dos mesmos, já que seu esgotamento está dialeticamente relacionado com sua contaminação; sendo esta relação coordenada com a forma de desenvolvimento desigual historicamente concretizada no capitalismo. Ou seja: o desenvolvimento desigual não se reduz à concentração da produção industrial, ao comércio, à população em áreas desenvolvidas, mas se estende à concentração na agricultura e à extração de matérias-primas em zonas subdesenvolvidas em que o "metabolismo básico" entre pessoas e natureza também foi perturbado (O’CONNOR, 2003, p. 15).

Podemos, portanto, concluir que o desenvolvimento desigual e o subdesenvolvimento aceleram a destruição da natureza. Este tipo de desenvolvimento tende a intensificar a contaminação e a expansão da degradação dos ecossistemas do planeta, ao mesmo tempo em que (e justamente em função disso) intensifica a superexploração do trabalho sob sua forma assalariada, o que aumenta a pobreza, em especial 
em áreas subdesenvolvidas, o que, por sua vez, acelera a degradação da natureza. O próprio autor constrói uma síntese esclarecedora:

Em suma, o desenvolvimento combinado significa a exportação da poluição e exportação de produtos perigosos - ambos meios de produção e meios de consumo. $\mathrm{O}$ que é transferido de Norte para Sul não é apenas capital e tecnologia, mas um conjunto de custos sociais e ambientais. Se vemos o mundo como cenário de acumulação de capital, no qual ocorrem ambas formas de desenvolvimento combinado no contexto de desenvolvimento desigual, podemos sugerir as seguintes hipóteses. Primeiro, a força de trabalho barata e carente de organização do Sul, as organizações trabalhistas enfraquecidas do Norte, são incapazes de resistir à destruição e aos danos ambientais e à saúde trabalhadores e comunidades. Em segundo lugar, a combinação de tecnologias complexas com mão-de-obra barata aumenta os "custos sociais", bem como as externalidades e a taxa de exploração em escala global, e, portanto, a taxa de lucro e, portanto, a taxa em que os recursos são usados e destruídos, bem como a taxa de poluição em todas as suas formas. O resultado é uma espiral de destruição ecológica e humana que se autoperpetua (O'CONNOR, 2003, p. 19).

Esta espiral de destruição tende a se ampliar espacialmente e a se intensificar ao longo do tempo, considerando a taxa de sobretrabalho, a qual depende da taxa composta de mais-valor. O cenário fica mais precário, pois, mesmo em períodos de crises cíclicas do capital, em especial aquelas causadas pela superprodução e pelas quedas nas taxas de realização, a destruição socioambiental não necessariamente diminui; paradoxalmente, tende a aumentar, em função da pauperização crescente, a qual conduz, dentre outras coisas, a problemas crescentes de saúde pública e à extrapolação dos limites de resiliência dos ecossistemas.

\section{Considerações finais}

De acordo com Burkett (2007), as discussões teóricas avançaram desde os anos 2000, especialmente no que se refere à presunção de que todos os gastos com manutenção ambiental representam reduções no valor agregado das mercadorias. Como resultado, o modelo explicativo reduziria a questão da crise ambiental a fatores estritamente econômicos, e se ignoraria a capacidade do capitalismo de reproduzir a suas próprias bases de atividades lucrativas, a despeito dos custos com a manutenção do meio ambiente e até mesmo diminuição de perdas monetárias com a degradação e com a gestão ambiental, em termos de ecoeficiência.

O pensamento ecossocialista atual promove a crítica materialista e histórica do contexto ecológico que é pano de fundo da produção e da organização social do capital. Isto é, as crises ecológicas (socioambientais) caracterizam-se por rupturas econômicas (uma crise de acumulação), porém é necessário que se faça a distinção entre crises econômicas que se explicam com a relação dos recursos naturais (meios de produção, matérias-primas, fontes de energia, processos ecossistêmicos) daquelas crises produzidas capitalisticamente que incidem nas condições ecológicas do desenvolvimento humano (coevolução humana com a natureza). A partir dessa distinção, ou seja, a partir da identificação das particularidades que definem tais crises, pode-se explicar dialeticamente a universalidade da crise econômica e socioambiental. Isso envolve a compreensão da economia capitalista como um processo de vida específico e estruturado 
em classes, no qual as formas de exploração da natureza são frutos históricos e veículos de exploração do trabalho assalariado.

Considerando os aspectos biológicos, físicos, químicos e sociais, ao se discutir a base material da produção, está-se a adentrar no âmbito da Economia Ecológica. O sistema produtivo demanda biomassa, combustíveis fósseis, diversos tipos de minérios e produz toda sorte de resíduos poluentes. Na esfera social, a desigualdade de acesso a recursos e a dívida ecológica dividida de forma não equitativa, onde os mais pobres são os mais atingidos pelos desastres "naturais", pelo regime de escassez/poluição e não usufruem dos recursos naturais necessários à sua sobrevivência - acaba por redundar em conflitos socioambientais, ou conflitos ecológico-distributivos: esse é o âmbito da Ecologia Política (MARTÍNEZALÍER, 2007).

Assim como não pode ser pensada uma economia sem a abstração sobre a sua organização político-social correlata, neste manuscrito, defende-se que a Economia Ecológica é um ramo da mesma Economia Política a que se referiu Karl Marx, mas com uma ênfase relevante na economia de recursos naturais. A Ecologia Política é sua contraparte que reflete as repercussões socioambientais do modo de produzir valores que são causas tanto das crises de escassez de recursos como dos processos de poluição/fragmentação/deleção de hábitats e espécies, o que compromete funções ecossistêmicas indispensáveis ao bem-estar social humano e de outras espécies.

A Economia Ecológica propõe uma visão de totalidade da relação entre economia e meio ambiente. A partir da categoria conflito, o economista-ecológico pode descrever o perfil do metabolismo social de um dado socioambiente, considerando demandas energéticas, demandas materiais, a demografia e a resiliência dos ecossistemas. Em decorrência, a Ecologia Política proporciona uma descrição dos conflitos ecológico-distributivos encontrados em diferentes ambientes (espaços e culturas) derivados do choque entre economia e meio ambiente (MARTÍNEZ-ALÍER, 2015). A Ecologia Política trata também da relação capital/natureza, considerando formas de apropriação/exploração, relações de poder e as consequências derivadas destes processos (ALIMONDA, 2015).

A concentração do capital resultou num quadro de destruição ecológica que é coerente com a interação entre concentração de riqueza e taxa de crescimento, ou seja, os países que são centros do capital global são os principais responsáveis pela destruição do planeta. Dentre outras constatações, isto foi o que levou Marínez-Alíer (2015) a concluir que o ecologismo dos pobres é o mais eficaz em termos econômicoecológicos do que os esforços do ambientalismo da ecoeficiência e do conservacionismo internacional.

O marxismo contribui à Economia Ecológica no que tange à ponderação dos recursos naturais, sejam renováveis ou não, em relação às demandas sociais produtivas e a critérios de decisão sobre modos de produção - unindo numa unidade dialética a economia, a ecologia e a política. No capitalismo, os valores de uso não são produzidos a partir de um plano racional voltado à satisfação das necessidades, mas para gerar lucro. Todavia, o lucro deve ser constantemente aumentado às custas do barateamento dos processos produtivos (incluindo o valor da mão de obra, evidentemente) e com o fim maior de alcançar 
uma taxa de crescimento constante e de promover a rotação/expansão do capital. Estes fatores são algumas das bases da explicação marxista da crise socioambiental (FOLADORI, 1999).

Lowy (2009) aponta que o Ecossocialismo busca fornecer alternativas para o assim chamado "progresso destrutivo", o qual Marx se referia. O Ecossocialismo trata de proposições de políticas econômicas que considerem tanto as demandas sociais como os limites naturais, mas que se fundamentam em critérios não monetários. Parte deste embate passa pela crítica à ideologia do progresso como sinônimo de crescimento econômico stricto senso, do consumismo e do individualismo; além de assumir um planejamento que priorize racionalmente uma economia que assuma explicitamente uma política valorativa claramente oposta à lei do valor de troca. Assim: “uma organização do modo de produção e de consumo é necessária, fundada em critérios exteriores ao mercado capitalista: as necessidades reais da população (não necessariamente 'pagáveis') e a preservação do meio ambiente (LÖWY, 2009, p. 52)”.

Entendemos, portanto, que os ecossocialistas não se limitam à crítica ou à proposição de soluções no âmbito econômico, vão além; e nem devem se limitar a ação política na esfera do Estado burguês. Propõem uma economia racionalmente planejada, de base comunal, tendo nos trabalhadores livremente associados produtores de bens genuinamente indispensáveis à manutenção da vida, respeitando os limites de resiliência ecossistêmica.

No que se refere à esfera da superestrutura, defendemos a ação política de superação da forma atual de produzir-distribuir-consumir os bens materiais necessários à reprodução da vida centrado no trabalho assalariado e na propriedade privada dos meios fundamentais de produção da nossa existência; passando a ter como centralidade a vida e não o capital. Vida essa só possível de existir na sua relação de complementariedade com a natureza. Isto posto, se faz necessário para isso uma revolução política com “alma social” (MARX, 2017b). Uma ação política que transforme a arma da crítica em crítica das armas (MARX, 2013)

O trabalho alienado parte do estranhamento do homem da natureza, ou seja, do seu afastamento de si mesmo. Como esclarece o próprio Marx (2006, p. 84): "na medida em que o trabalho estranhado estranha do homem a sua natureza, e o homem de si mesmo, de sua função ativa, de sua atividade vital, ele estranha o homem do gênero humano". O ser humano, ao invés de constituir-se enquanto espécie genérica, constitui-se individualmente já que no capitalismo a produção baseia-se na propriedade privada dos meios de produção e o capitalista detém o poder maior de desfrutar o trabalho alheio, pois sob o trabalho assalariado o trabalhador não tem outra saída a não ser vender sua força de trabalho para sobreviver. Como o trabalho é alienado, seu resultado lhe é alheio: nenhum trabalhador virá a usufruir do resultado do seu trabalho.

No âmbito político, em específico na gestão pública, cabe propor alternativas viáveis de enfrentamento das condições desiguais impostas historicamente. Desta forma, de acordo com Löwy (2020), almeja-se uma economia planejada a partir de critérios sociais e ecológicos de produção de mercadorias que atendam necessidades genuínas, superando a produção de valores de troca inúteis, descartáveis e obsolescentes. O critério fundamental seria a autogestão dos trabalhadores livremente 
associados, com vista a um planejamento ecológico de base comunal. Michael Löwy, por fim, faz um resgate inadiável do pensamento de Marx e Engels, que segundo ele, se opuseram fortemente ao chamado "produtivismo" e ao crescimento ilimitado em termos econômicos crematísticos, indo de encontro à lógica acumulativa do capital, propunham a sociedade do "ser" acima do "ter". Uma sociedade planejada racionalmente para a produção de bens indispensáveis e ambientes essencialmente voltados à reprodução da vida digna e ecologicamente equilibrada, em suas mais variadas formas. 
Referências:

AGUIAR, N; BASTOS, J. V;. Uma reflexão teórica sobre as relações entre natureza e capitalismo. Revista Katálysis, Florianópolis, v. 15, n. 1, 2012.

ALIMONDA, H. Ecología política latinoamericana y pensamiento crítico: vanguardias arraigadas. Curitiba, Desenvolvimento e meio ambiente, v. 35, 2015.

ALTVATER, E. Existe um marxismo ecológico? In: BORON, A. A.; AMADEO, J.;GONZÁLEZ, S. (Orgs.). La teoría marxista hoy: problemas y perspectivas. Buenos Aires: CLACSO, 2006.

BURKET'T, P. Two Stages of Ecosocialism? Implications of some neglected analyses of ecological conflits and crises. International journal of Political Economy, v. 35, n.3, 2006.

CHASIN, J. Método dialético. Maceió, s/d, (mimeo).

DANTAS, G. Por que é necessário criticar um certo “marxismo ecológico”.Parte I: J. O’Connor 19302017. Esquerda diário. Disponível em: http://www.esquerdadiario.com.br/Por-que-e-necessariocriticar-um-certo-marxismo-ecologico-Parte-I-J-O\%C2\%B4Connor-1930-2017. Acesso em: 15 mar. 2021.

DUSSEL, E. La cuestión ecológica en Marx. In: Cultura y Naturaleza. MARTÍNEZ, L. M (ORG.). Bogotá: Jardín Botánico de Bogotá, José Celestino Mutis, Mayo 2011.

ENGELS, F. Anti-Dühring: a revolução da ciência de acordo com o senhor Eugene Dühring. São Paulo: Boitempo, 2015.

FOLADORI, G. Marxismo e meio ambiente. Revista de Ciências Humanas, Florianópolis, n. 25, 1999. FOLADORI, G. O metabolismo com a natureza. Revista Crítica Marxista, São Paulo, n. 11, p. 105-117, 2001.

FOLADORI, G. Degradação ambiental no capitalismo e no socialismo. Revista Outubro, n. 13, 2005.

FOSTER, J. B; MAGDOFF, F. Liebig, Marx and the exhaustion of soil fertility: relevance for agriculture today. Nova York, Monthly Review, v. 50, n. 3, 1998.

FOSTER, J. B. La ley general e absoluta de la degradacion ambiental en el capitalismo. Ecologia politica. Barcelona, n.4, 1992.

FOSTER, J. B. The nature of the contradiction. Montly review. Dosponível em: https://monthlyreview.org/2002/09/01/capitalism-and-ecology/. Acesso em: 10 mar. 2021.

FOSTER, J. B. A ecologia de Marx: materialismo e natureza. Rio de Janeiro: Civilização Brasileira, 2005.

FOSTER, J. B. A ecologia da economia política marxista. Lutas Sociais, São Paulo, n.28, 2012.

FOSTER, J. B. Marxismo e ecologia: fontes comuns de uma grande transição. Lutas Sociais, São Paulo, vol.19 n.35, p.80-97, jul./dez. 2015.

GRAMSCI, A. Concepção dialética de história. Rio de Janeiro: Civilização Brasileira, 1996.

HARVEY, D. O enigma do capital: e as crises do capitalismo. São Paulo: Boitempo, 2011.

HARVEY, D. 17 contradições e o fim do capitalismo. São Paulo: Boitempo: 2016.

LEFEBVRE, H. Marxismo. Porto Alegre, RS: L\&PM, 2010.

LESSA, S. A centralidade ontológica do trabalho em Lukács. Serviço Social \& Sociedade, n. 52, 1996.

LESSA, S. Lukács - Ética e política: observação acerca dos fundamentos ontológicos da ética e da política. Chpecó: Argos, 2007.

LESSA, S; TONET, I. Introdução à filosofia de Marx. São Paulo: Expressão Popular, 2011.

LÖWY, M. Eco-socialismo e planejamento democrático. Crítica Marxista, São Paulo, n.28, 2009. 
LÖWY, M. Ecosocialismo: uma síntese vital. Climate \& capitalism. Disponível em:https://climateandcapitalism.com/2020/12/16/ecosocialism-a-vital-synthesis/. Acesso em: 20 dez. 2020.

LUKÁCS, G. Prolegômenos para uma ontologia do ser social: questões de princípios para uma ontologia hoje tornada possível. São Paulo: Boitempo, 2010.

MARTÍNEZ-ALÍER, J. El ecologismo popular. Ecosistemas, Barcelona, v. 16, n. 3, 2007.

MARTÍNEZ-ALÍER, J. O ecologismo dos pobres: conflitos ambientais e linguagens de valoração. São Paulo: Contexto. 2015.

MARX, K; ENGELS, F. A ideologia alemã. Lisboa: Editorial “Avante!”, 1982.

MARX, K. O capital: o processo de produção do capital. Rio de Janeiro: Civilização Brasileira, Livro 1, v.1. 1980.

MARX, K. Teses sobre Feuerbach (1845). Versão para ebooks. Rocket Edition, 1999.

MARX, K. Manuscritos econômico-filosóficos de 1844. São Paulo: Martin Claret, 2006.

MARX, K. Contribuição à Crítica da Economia Política. São Paulo: Expressão Popular, 2007.

MARX, K. Manuscritos econômicos-filosóficos. São Paulo: Boitempo, 2008a.

O capital: crítica da economia política. Livro I. v. 1. Rio de Janeiro: Civilização Brasileira, 2008b.

MARX, K. O capital: crítica da economia política. Livro 1, Tomo 2. São Paulo: Abril Cultural, 1984.

MARX, K. Grundrisse: manuscritos econômicos de 1857-1858: esboços da crítica da economia política. São Paulo: Boitempo, 2011.

MARX, K. Crítica da Filosofia do Direito de Hegel, 1843. 3 ed. São Paulo: Boitempo, 2013.

MARX, K. Os despossuídos: debates sobre a lei referente ao furto de madeira. São Paulo: Boitempo, 2017 a.

MARX, K. Glosas marginais ao Manual de economia política de Adolph Wagner. Verinotio - Revista online de Filosofia e Ciências Humanas, Rio de Janeiro, v. 23, n. 2, $2017 \mathrm{~b}$.

MÉSZÁROS, I. A crise estrutural do capital. São Paulo: Boitempo, 2009.

NETTTO, J. P; BRAZ, M. Economia política. Tomo 1. São Paulo: Cortez, 2009.

O'CONNOR, J. Capitalism, nature, socialism: a theoretical introduction. Capitalism, Nature, Socialism, Londres, v. 1 n. 1, 1988.

O’CONNOR, J. Desarrollo desigual y combinado y crisis ecológica. Ambiente e Sociedade, Campinas, v.6, n.2, 2003.

\footnotetext{
Notas

${ }^{1}$ Doutor em Ensino, filosofia e história das ciências pela Universidade Federal da Bahia (UFBA). Atualmente está vinculado ao Grupo de estudo e pesquisa em educação do campo (Gepec) - dgp.cnpq.br/dgp/espelhogrupo/6187765896665435. Currículo Lattes: http://lattes.cnpq.br/6426014773951663. Orcid: http://orcid.org/0000-0001-6015-0295. E-mail: bio.magno@gmail.com.

2 Doutor em Ensino, filosofia e história das ciências pela Ufba/Uefs. Pós-Doutorado em Educação/Ufba (2013), Pós-Doutorado em Educação em Ciências/Uesc (2017), Pós-Doutorado na Faculdade de Letras, Departamento de Filosofia da Universidade de Lisboa/FLUL (2018) e Pós-Doutorado em Educação na Universidade Federal de Santa Catarina/Ufsc (2018). Atualmente é professor titular do Instituto de Química da Ufba, da Faculdade de Educação da Ufba e do Programa de Pós-Graduação em Ensino, filosofia e história das ciências da Ufba/Uefs. Membro do Grupo de Pesquisa em Ensino de Ciências e Formação de Professores - Ufba, do Grupo de Estudo e Pesquisa em Educação do Campo (Gepec/Ufba) e do Grupo de Pesquisa em Ensino
} 
Concreto de Ciências (ENCONCiÊNCIAS) da Ufba - dgp.cnpq.br/dgp/espelhogrupo/0569762712320378. Currículo Lattes: http://lattes.cnpq.br/8466534604937618. Orcid: http://orcid.org/0000-0001-5457-3718. E-mail: edilson@ufba.br.

${ }_{3}^{3}$ Dieta Renana é a assembleia de representantes da burguesia que debatia o ordenamento legal que o estado alemão mantinha sob sua tutela distritalmente. Não confundir com o famoso periódico, a Gazeta Renana.

${ }^{4}$ Para efeito didático, estamos chamando de natureza-natural a natureza sem os seres humanos e chamando de natureza a natureza na sua máxima complexidade, isto é, contento todas as três grandes dimensões da materialidade historicamente constitutiva da realidade objetiva atual: a matéria inorgânica (domínio dos processos físico-químicos), a matéria orgânica (aparecimento da vida, domínio dos processos biológicos) e a matéria social (aparecimento da consciência, domínio do trabalho como ação deliberada sobre a natureza). Retomaremos esse ponto mais à frente do texto.

${ }^{5} \mathrm{Na}$ atividade produtiva, a relação direta do homem coma a natureza se trata de uma mediação de primeira ordem. As mediações de segunda ordem se referem já às formas de mediações realizadas no seio das sociedades caracterizadas pela divisão do trabalho, pela propriedade privada e pelo intercâmbio (MÉSZÁROS, 2006).

${ }^{6}$ De uma forma rápida, para não deixar passar em branco, entendemos a ética como um complexo social que aparece historicamente com a função social de resolver os conflitos entre o "eu” e o "nós", conflitos esses que jamais se resolvem, já que a totalidade social está em movimento, pondo novas questões e determinações na realidade objetiva social. Entretanto, na resolução desses conflitos, em determinado contexto sócio-histórico, o polo determinante da sua resolução é o "nós". É a isto que chamamos de ética imanente, a partir de Marx, em contraposição a uma ética transcendente dominante atualmente na sociedade reprodutora do capital. Desse nosso ponto de vista, costumamos dizer que a sociedade burguesa não tem "ética", pois seus valores se estruturam no individualismo burguês, no "eu” (LUKÁCS, 2010; LESSA, 2007).

${ }^{7}$ Não se deve confundir o sentido de teleologia utilizado pelo filósofo húngaro. Assume-se aqui uma atividade com um fim previamente posto, mas de caráter imediato, no âmbito da práxis. Em nenhum momento Lukács nega o caráter não teleológico da evolução biológica em geral, mesmo quando se refere à evolução humana. Pois nos seres humanos o pôr teleológico é extremamente limitado pela imediaticidade da práxis humana e pelo "complexo de complexos" que compõe sua sociedade. Como esclarece Ester Vaisman na apresentação dos Prolegômenos: segundo o filósofo húngaro a categoria da generidade explicita a concepção revolucionária sobre o ser e o devir humano instaurada por Marx. Lukács identifica o lugar genético dessa concepção, isto é, da superação do gênero mudo natural e o advento do gênero propriamente humano, precisamente na práxis que constitui o modo por meio do qual se processa a "adaptação ativa" e a partir da qual se dá, de modo contraditório e desigual, a constituição processual do ser social. Em outros termos, "a base ontológica do salto [do gênero mudo para o gênero não-mais-mudo] foi a transformação da adaptação passiva do organismo ao ambiente em uma adaptação ativa, com o que a sociabilidade surge como nova maneira de generidade.

${ }^{8}$ Superestrutura e infraestrutura e infraestrutura se refere, segundo a concepcão de A. Gramsci, ao componente do bloco histórico composto pela estrutura produtiva econômica (infraestrutura) e o Estado, as ideologias, a sociedade civil e suas instituições (superestrutura).

${ }^{9} \mathrm{Na}$ atividade produtiva, a relação direta do homem coma a natureza se trata de uma mediação de primeira ordem. As mediações de segunda ordem se referem já às formas de mediações realizadas no seio das sociedades caracterizadas pela divisão do trabalho, pela propriedade privada e pelo intercâmbio (MÉSZÁROS, 2006).

${ }^{10} \mathrm{O}$ presente artigo tem seu escopo bastante circunscrito, embora não possamos deixar de lembrar pensadores que contribuíram de maneira importante à discussão sobre Economia Ecológica, tais como: André Gorz, Raymond Williams, Michael Perelman, Richard England e Thomas Weisskopf, apenas para citarmos alguns.

Recebido em: 08 de junho de 2021

Aprovado em: 16 de julho de 2021 